\title{
Geology and Mineral Deposits of the Needle Mountains District,
}

\section{Southwestern Colorado}

G E O L O G I C A L S U R V E Y B U L L E T IN 1434 

GEOLOGY AND MINERAL DEPOSITS OF THE NEEDLE MOUNTAINS DISTRICT, SOUTHWESTERN COLORADO 


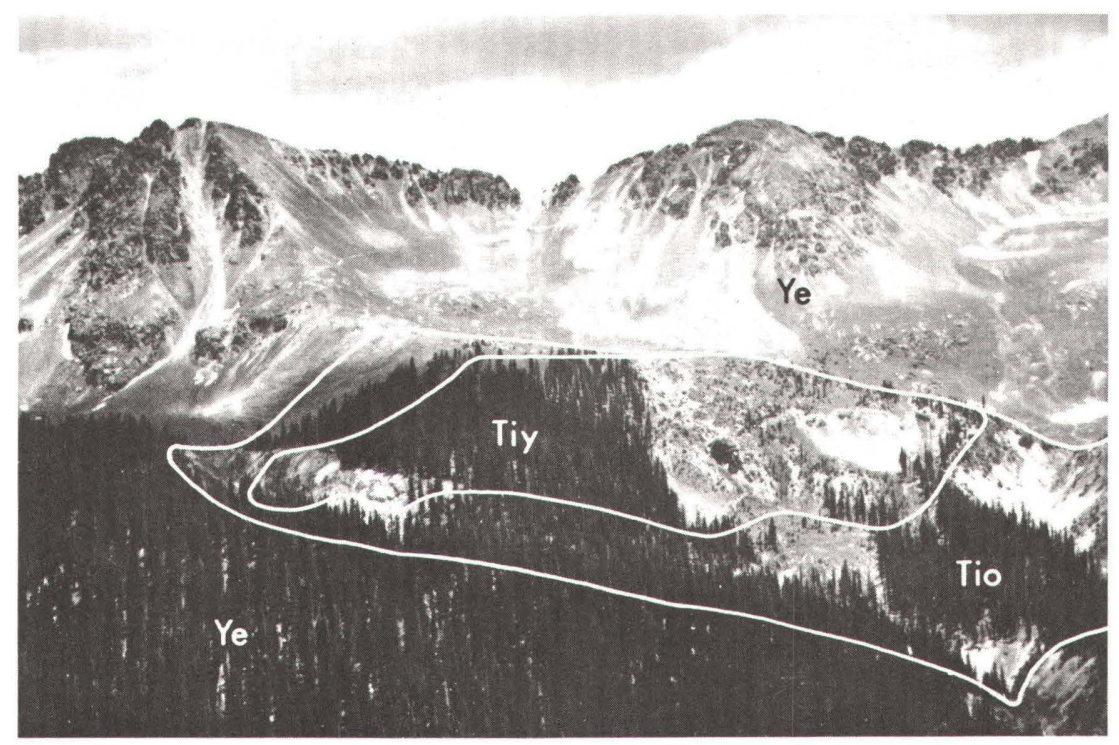

Precambrian Eolus Granite intruded by Tertiary stock in Chicago Basin. View southeast toward Columbine Pass (center of skyline). (Ye, Precambrian Y Eolus Granite; Tio, Tertiary older intrusive body; Tiy, Tertiary younger intrusive body.) 


\section{Geology and Mineral Deposits of the Needle Mountains District, Southwestern Colorado}

By L. J. SCHMITT and W. H. RAYMOND

G E O L O G I C A L

$A$ detailed study of the mineral potential

of complex intrusive rocks and

associated alteration of the

Needle Mountains district, Colorado

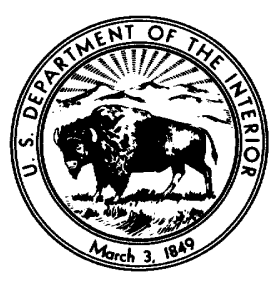




\title{
UNITED STATES DEPARTMENT OF THE INTERIOR
}

\author{
CECIL D. ANDRUS, Secretary
}

\section{GEOLOGICAL SURVEY}

V. E. McKelvey, Director

Library of Congress Cataloging in Publication Data

Schmitt, Leonard J.

Geology and mineral deposits of the Needle Mountains district, southwestern Colorado. (Geological Survey Bulletin 1434)

Bibliography: p. 39

Supt. of Docs. no.: I 19.2:1434

1. Mines and mineral resources-Colorado-Needle Mountains.

2. Geology-Colorado-Needle Mountains.

I. Raymond, William H., joint author. II. Title. III. Series:

$$
\text { United States Geological Survey Bulletin } 1434
$$

QE75.B9 no. 1434 [TN24.C6] 557.3'08s [553'.09788'29] 76-608394

For sale by the Superintendent of Documents, U.S. Government Printing Office

Washington, D.C. 20402

Stock No. 024-001-03029-2 


\section{CONTENTS}

\begin{tabular}{|c|c|}
\hline & Page \\
\hline \multicolumn{2}{|l|}{ 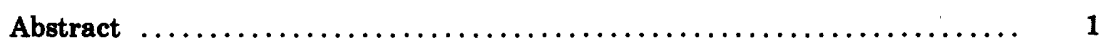 } \\
\hline 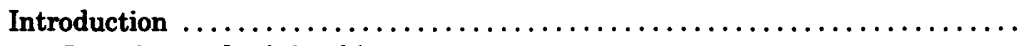 & 2 \\
\hline Location and mining history .... & 2 \\
\hline Previous investigations $\ldots \ldots \ldots$ & 5 \\
\hline Present investigation ........ & 5 \\
\hline Acknowledgments $\ldots \ldots \ldots \ldots \ldots \ldots \ldots \ldots \ldots \ldots \ldots \ldots \ldots \ldots \ldots$ & 5 \\
\hline 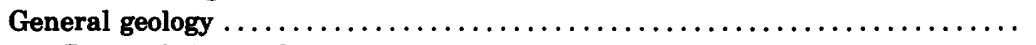 & 6 \\
\hline 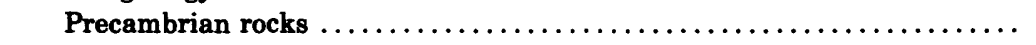 & 6 \\
\hline Paleozoic rocks $\ldots \ldots \ldots \ldots \ldots \ldots \ldots$ & 7 \\
\hline Tertiary rocks $\ldots \ldots \ldots \ldots \ldots \ldots \ldots$ & 8 \\
\hline Older intrusive body and related rocks $\ldots \ldots \ldots \ldots \ldots \ldots \ldots \ldots$ & 8 \\
\hline 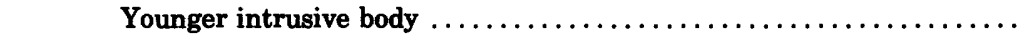 & 11 \\
\hline ike $\ldots \ldots \ldots \ldots \ldots \ldots \ldots \ldots \ldots \ldots \ldots \ldots \ldots \ldots \ldots \ldots \ldots \ldots$ & 13 \\
\hline 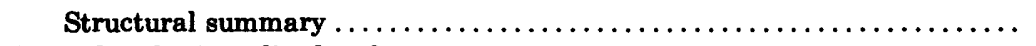 & 13 \\
\hline Altered and mineralized rocks $\ldots \ldots \ldots \ldots \ldots \ldots \ldots \ldots$ & 14 \\
\hline Sampling and analytical techniques . & 14 \\
\hline 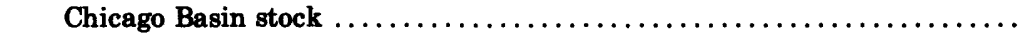 & 15 \\
\hline Alteration minerals of older intrusive rocks $\ldots \ldots \ldots \ldots \ldots \ldots \ldots$ & 16 \\
\hline Chemical compositions of older intrusive rocks $\ldots \ldots \ldots \ldots \ldots \ldots$ & 20 \\
\hline Significance of alteration features $\ldots \ldots \ldots \ldots \ldots \ldots \ldots \ldots \ldots \ldots$ & 23 \\
\hline Geochemical investigations of the older intrusive rocks $\ldots \ldots \ldots \ldots$ & 25 \\
\hline Alteration minerals and chemical compositions of & \\
\hline & 28 \\
\hline Geochemical investigations of the younger intrusive rocks..$\ldots \ldots \ldots$ & 29 \\
\hline 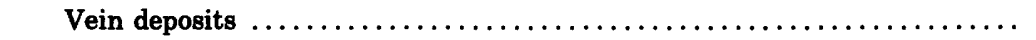 & 30 \\
\hline$\ldots \ldots \ldots \ldots \ldots \ldots \ldots \ldots \ldots \ldots \ldots \ldots$ & 30 \\
\hline Mineralogy and paragenesis $\ldots \ldots \ldots \ldots \ldots \ldots \ldots \ldots \ldots \ldots \ldots$ & 30 \\
\hline Structural control $\ldots \ldots \ldots \ldots$ & 33 \\
\hline Geochemical investigations ... & 34 \\
\hline eologic implications $\ldots \ldots \ldots \ldots \ldots \ldots$ & 38 \\
\hline (n) & 39 \\
\hline
\end{tabular}

\section{ILLUSTRATIONS}

FroNTISPIECE. Eolus Granite intruded by Tertiary stock in Chicago Basin.

Plate 1. Geologic map of the Needle Mountains district, southwestern Colorado $\ldots \ldots \ldots \ldots \ldots \ldots \ldots \ldots \ldots \ldots \ldots \ldots$ In pocket

FIGURE 1. Index map of southwestern Colorado showing the location of the Needle Mountains district $\ldots \ldots \ldots \ldots \ldots \ldots \ldots \ldots \ldots \ldots, \quad 3$

2. Drainage map of the southern Needle Mountains ......... 7 
FIGURE 3. Map of the Chicago Basin stock showing locations of altered rock samples and their alteration mineral assemblages ....

4. AKF compatibility diagram for older intrusive rocks in the Chicago Basin stock .........................

5. AKF compatibility diagram for rock samples of dikes related to the older intrusive body in the Chicago Basin stock ........

6. AKF compatibility diagram for samples of younger intrusive rocks from the Chicago Basin stock .................

7. Sketch map of the mineralized area showing interrelations between geochemical anomalies, rock alteration, and geology .

\section{TABLES}

TABLE 1. Modal analyses of least altered rock samples of the Chicago Basin stock .................................

2. Rapid rock analyses of least altered samples of the Chicago Basin stock ...

3. Alteration minerals in samples from the Chicago Basin stock and immediate vicinity

4. Rapid rock analyses of altered samples from the older intrusive body in the Chicago Basin stock ...

5. Rapid rock analyses of samples from dikes related to the older intrusive body in the Chicago Basin stock ...............

6. Limits of detection by different analytical methods for elements considered geochemically significant and levels of concentration considered anomalous

7. Rapid rock analysis of altered sample of the younger intrusive body in the Chicago Basin stock

\section{ENGLISH-METRIC EQUIVALENTS}

\begin{tabular}{llc}
\hline English unit & & Metric equivalent \\
\hline inch & $=$ & 2.54 centimeters \\
foot & $=$ & .3048 meter \\
mile & $=$ & 1.6 kilometers \\
square mile & $=$ & 2.6 square kilometers \\
ounce $(\mathrm{oz})$ & $=$ & 28 grams \\
pound $(\mathrm{lb})$ & $=$ & .45 kilogram \\
ton & $=$ & .9 tonne (megagram) \\
\hline
\end{tabular}




\title{
GEOLOGY AND MINERAL DEPOSITS OF THE NEEDLE MOUNTAINS DISTRICT, SOUTHWESTERN COLORADO
}

\author{
By L. J. SchmitT and W. H. RAYMOND
}

\section{ABSTRACT}

The Needle Mountains district is set in highly fractured Precambrian granitic rocks that have intruded and metamorphosed older Precambrian metasedimentary rocks. The Precambrian rocks are overlain by outliers of Paleozoic strata and intruded by an upper Tertiary stock. Past mineral production reportedly was limited to silver and gold ores presumably taken from small fissure veins. Although the economic potential of the district has not been adequately explored, some evidence indicates potential for basemetal deposits.

Mineral deposits are spatially related to a conspicuously altered composite stock, about 2,600 feet wide and 3,500 feet long. The stock consists mainly of an older porphyry body intruded by a younger porphyry body. The older body is composed of pervasively altered granite porphyry or quartz porphyry and related brecciated rocks. A coarser grained core is gradational with a finer grained, flow-structured outer phase. Least altered samples of the coarser porphyry contain sanidine and quartz phenocrysts set in a fine-grained micrographic groundmass of quartz and alkali feldspar. The younger body is composed of variably altered rhyolite porphyry that contains sanidine, plagioclase, quartz, biotite, and sphene phenocrysts set in an aphanitic to microgranular, flow-structured groundmass. Mineralogical, textural, and structural criteria indicate that the stock was emplaced at a shallow depth.

The older body in the stock has been altered to quartz-sericite-pyrite or quartzsericite-kaolinite-pyrite assemblages in nearly all exposed rocks. A zonal distribution of sericite polytypes indicates a focus of intense alteration on the west side of the body. There, molybenite is locally concentrated along thin quartz veinlets and is disseminated through some of the intensely altered rocks, and $\mathrm{As}, \mathrm{Au}, \mathrm{Cu}, \mathrm{Sb}$, and $\mathrm{Sn}$ occur in anomalous concentrations. These features suggest $\mathrm{Mo}-\mathrm{Cu}$ resource potential below the surface in the western part of the stock, whereas other evidence indicates potential subsurface metallization in the eastern part of the stock.

In places, fractures in Precambrian rocks have been filled with quartz or quartzpyrite veins. Veins are controlled mostly by north-or east-trending regional fractures, but also by fractures discordant with these trends. Many veins containing ore shoots of base metals are in a north-trending belt about 2 miles wide and 4 miles long. The northern part of the metallized belt is intersected by an east-trending zone of fractures. The area of intersecting structural zones includes the Chicago Basin stock and a concentration of metallized veins.

Dump rock from mine workings along veins contains significant quantities of sphalerite, galena, and chalcopyrite, and lesser tetrahedrite in a gangue of quartz, 
pyrite, rhodochrosite, and fluorite. Sphalerite appears to decrease relative to galena away from the stock. Fluorite was found around the stock and in the area to the southeast. Anomalous amounts of $\mathrm{Ag}, \mathrm{As}, \mathrm{Au}, \mathrm{Ba}, \mathrm{Bi}, \mathrm{Cd}, \mathrm{Mn}, \mathrm{Mo}, \mathrm{Sb}, \mathrm{Sn}$, and $\mathrm{W}$, in addition to abundant $\mathrm{Cu}, \mathrm{Pb}$, and $\mathrm{Zn}$, are associated with the veins. The distribution patterns for several metal anomalies indicate a focus of metallization southeast of the Chicago Basin stock. Evidence suggests that a pluton related to the Chicago Basin stock may underlie the area southeast of the stock.

\section{INTRODUCTION}

The Needle Mountains district lies within a domal uplift of Precambrian rocks about 25 miles in diameter in the southwest part of the San Juan Mountains, southwestern Colorado (fig. 1). Tilted Paleozoic and Mesozoic sedimentary rocks cover the south and west flanks of the uplift, whereas Oligocene volcanic rocks, part of the large volcanic field that covers the remainder of the San Juan Mountains, lap onto the north flank. Mineralization in the district is manifested by an upper Tertiary highly altered hypabyssal stock and numerous outlying quartz-sulfide fissure veins. The stock, located in Chicago Basin, is composed of two principal intrusive bodies-an altered and mineralized horseshoe-shaped body of older porphyry and related rocks, and a central body of younger porphyry -and a small late dike. The stock is surrounded by Precambrian Y Eolus Granite and Trimble Granite which are cut by fractures of diverse orientation. Many of the fractures are filled with quartz-pyrite veins that locally have ore shoots of sphalerite, galena, chalcopyrite, and tetrahedrite.

A geologic map (pl. 1) was prepared showing the stock and many of the veins and fractures. Microscopic and X-ray diffraction methods were used to identify alteration mineral assemblages in rock samples. Spectrographic, colorimetric, atomic absorption, and rapid rock analytical methods were used by the U.S. Geological Survey to analyze rock samples representative of the stock and selected samples of altered rock and vein materials. Metal anomalies were compared with the alteration pattern in the stock to determine whether any definitive relationships exist and to evaluate their possible significance. Geochemical data were used to determine the distributions of certain metals over the district and to relate the patterns of distribution to the fracture-vein system. The results of this study indicate that the district may have significant economic potential.

\section{LOCATION AND MINING HISTORY}

The Needle Mountains district (fig. 1), about 15 miles south of Silverton and about 27 miles northeast of Durango, is accessible from the west by a trail that follows the trace of an old wagon road along Needle Creek from Needleton on the Animas River to Chicago Basin. Needleton is a whistlestop for the Denver and Rio Grande narrow- 


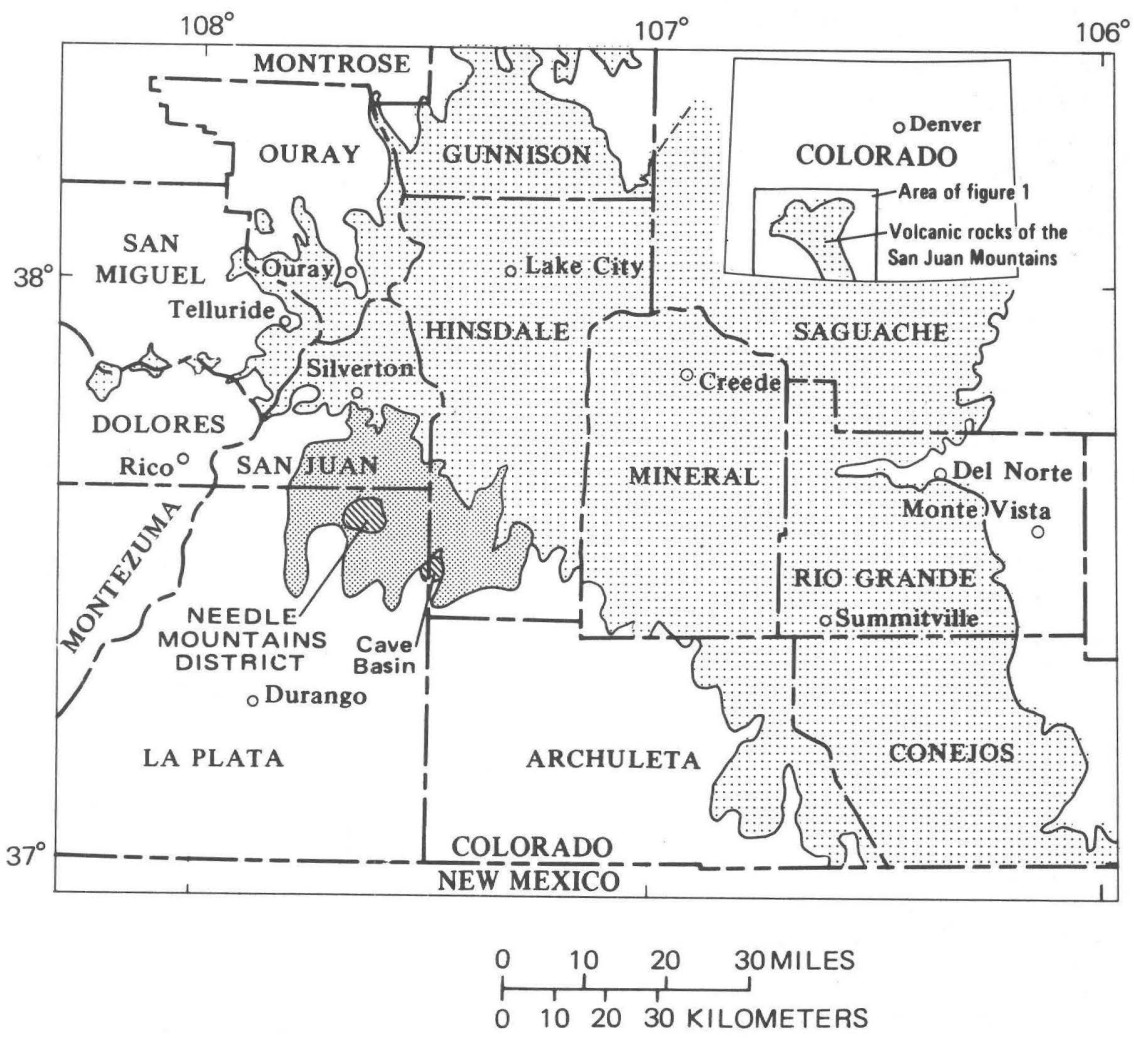

FIGURE 1.-Index map of southwestern Colorado showing the location of the Needle Mountains district (crosshatched). Area of heavy shading is Tertiary volcanic rocks; area of light shading is Precambrian crystalline rocks.

gage railroad between Durango and Silverton. Access from Durango is by old logging roads to Lime Mesa and Endlich Mesa, but these roads reach only the perimeter of the district. Travelers into the district are advised to use four-wheel-drive vehicles.

The rugged terrain, which has about 6,000 feet of relief, is drained primarily by west-flowing Needle Creek and east-flowing Johnson Creek. Chicago Basin and Vallecito Basin are compound cirques developed at the headwaters of Needle Creek and Johnson Creek, respectively. The southern part of the district is characterized by gently south sloping mesas dissected by Missouri Gulch and Crystal Valley. The south-flowing Animas River and Vallecito Creek mark the western and eastern limits, respectively, of the Needle Mountains district.

Many of the mining districts in the greater San Juan Mountains region were discovered in the 1870's (Larsen and Cross, 1956, p. 
3-4), and the Needle Mountains district was examined and prospected at least as early as 1881 (Henderson, 1926, p. 52, 177). Cross, Howe, Irving, and Emmons (1905, p. 12) reported that extensive prospecting had been carried on until the time of their study, but that production was minor and was restricted largely to oxidized ores of gold and silver. They stated that veins where unoxidized were uniformly low grade, and probably would average no more than $\$ 19$ per ton in gold, silver, and copper (prices prevailing in 1905). The value of the ore metals (largely silver) in the veins where oxidized and secondarily enriched was reportedly as high as $\$ 1,800$ per ton (1905 prices), but oxidation was generally shallow and primary ore was commonly found within a few feet of the surface.

Production records for the Needle Mountains district are spotty and some are obscure, but some records are available from the files of the Colorado State Bureau of Mines (M. J. Sheridan, U.S. Bur. Mines, oral commun., 1968). Records of the nature and amount of production before 1900 are lacking. In 1901 the Aztec mine in southern Chicago Basin yielded a small but unknown tonnage of pyritic ore valued at $\$ 5-\$ 150$ per ton, presumably largely in silver. In 1904 the Aetna mine in southern Chicago Basin yielded 35 tons of ore containing a total of 1 oz of gold and $4 \mathrm{oz}$ of silver. In 1905 the same mine yielded 42 tons of ore containing $3 \mathrm{oz}$ of gold and 3,823 oz of silver, and in 1906, 42 tons containing $61 \mathrm{oz}$ of gold, $1,867 \mathrm{oz}$ of silver, $440 \mathrm{lbs}$ of copper, and 1,298 lbs of lead. In 1917 the Eureka mine in northern Vallecito Basin yielded 9 tons of ore containing one-half oz of gold, $177 \mathrm{oz}$ of silver, 340 lbs of copper, and $920 \mathrm{lbs}$ of lead. The total recorded production between 1904 and 1917 is 128 tons of ore containing $66 \mathrm{oz}$ of gold, $5,871 \mathrm{oz}$ of silver, $780 \mathrm{lbs}$ of copper, and 2,218 lbs of lead. Although these figures do not represent the total production of the Needle Mountains district, they are representative of the type of ore mined and of the sporadic history of mining activity.

According to Vanderwilt, Burbank, and Traver (1947, p. 135-137), production from the district was recorded in 1934 when 49 tons of ore was shipped yielding 80 oz of gold, and in 1935 and 1936 when Vallecito Basin was credited with 13 tons containing $29 \mathrm{oz}$ of gold and $4 \mathrm{oz}$ of silver. However, M. J. Sheridan of the U.S. Bureau of Mines (oral commun., 1968) reported that these figures should have been credited to Cave Basin, an area of small production well outside the Needle Mountains district to the southeast (fig. 1).

Worcester (1919, p. 68-69) reported that molybdenite was found on East Silver Mesa within 2,000 feet of Lake Lillie, where some 4-inchwide quartz veins contained 1-2 percent $\mathrm{MoS}_{2}$. In 1960 American Metals Climax, Inc., began a geochemical survey of the Chicago Basin stock. On the basis of a surficial molybdenum anomaly, the company 
core-drilled to a depth of about 1,000 feet, but they found no ore-grade concentrations of molybdenum, and therefore they discontinued the exploration.

Approximately 125 patented lode claims have been recorded in the Needle Mountains district, and some unpatented claims exist. Numerous adits and shafts have been dug on the veins; none of the workings exceed a total of a few hundred yards.

\section{PREVIOUS INVESTIGATIONS}

The only significant published description of the mineral deposits in the Needle Mountains district is that by Cross, Howe, Irving, and Emmons (1905, p. 12-13). A description of the geology of the Needle Mountains given by Larsen and Cross (1956, p. 18-19, 23-32) was derived largely from the earlier work by Cross and associates. More recently Barker (1969) restudied the Precambrian rocks as part of a regional study by the U.S. Geological Survey of the Durango $1^{\circ} \times 2^{\circ}$ quadrangle. Barker brought up to date the descriptions and structural relations, obtained radiometric age data for Precambrian units, and sampled several Precambrian units for evaluation of their mineral potential.

\section{PRESENT INVESTIGATION}

The present study was undertaken as part of the Heavy Metals Program of the U.S. Geological Survey to describe the mineral deposits in this isolated and little-known district, and as part of a study to evaluate the mineral resources of the San Juan Primitive Area (Steven and others, 1969). The Needle Mountains district, because of the widespread evidence of mineralization and because of its history of production, was studied in more detail than less promising terrain in the primitive area. Most of the work was accomplished from a spike camp in Chicago Basin with access by helicopter during July 1967; the remainder was completed from a spike camp at Logtown during late June and early July 1968, with access by horse and pack mule.

\section{ACKNOWLEDGMENTS}

T. A. Steven and R. U. King of the U.S. Geological Survey were helpful in developing many of the ideas set forth in the text. J. Ashback and J. A. Kroeger and Associates of Durango, Colo., provided unpublished reports, maps, and assays and were cooperative in all phases of the work. The cooperation of M. J. Sheridan and Paul Mcllroy of the U.S. Bureau of Mines is gratefully acknowledged. R. E. Van Loenen and W. K. Mensing of the U.S. Geological Survey served as part-time field assistants. 


\section{GENERAL GEOLOGY}

In the Needle Mountains district Precambrian granites, cut by numerous generally north and east trending fractures, are overlain by outliers of Paleozoic sedimentary rocks and are intruded by an upper Tertiary composite stock. Faulting was never extensive, but opening of old regional fractures, radial fracturing, and transverse fracturing developed probably in response to intrusion of the stock.

\section{PRECAMBRIAN ROCKS}

Precambrian rocks of the Needle Mountains are discussed in detail by Barker (1969), Cross, Howe, Irving and Emmons (1905), and Larsen and Cross (1956); and the following rock descriptions are based largely on these works. Eolus Granite and Trimble Granite (Precambrian Y), named by Cross, Howe, Irving, and Emmons (1905), surround a mineralized Tertiary stock, and they host most of the exposed metallized veins. Bodies of amphibolite, gneiss, and schist of the Irving Formation (Precambrian $\mathrm{X}$ ) in the western part of the district contain a few metallized veins or shear zones.

Amphibolite, quartzo-feldspathic gneiss, and biotite schist of the Irving Formation form the intensely metamorphosed wall of the Eolus batholith exposed along lower Needle Creek in the western part of the Needle Mountains district (pl. 1). Foliation in the metamorphosed rocks trends northeast and commonly dips nearly vertically. The amphibolite is nearly black, commonly fibrous textured, and is composed largely of hornblende with considerable quartz and plagioclase, some biotite, and accessory magnetite, sphene, and apatite. Garnet amphibolite is abundant locally. The gneiss is light colored, coarse textured, and composed chiefly of quartz, feldspar, and lesser biotite, with variable amounts of hornblende, epidote, and muscovite, and accessory apatite, magnetite, sphene, and zircon. The biotite schist contains similar minerals but is generally darker colored and finer textured than the gneiss.

A composite batholith of Eolus Granite forms the major part of the Needle Mountains uplift in southwestern Colorado. Most of the Eolus Granite is a massive gray to red, medium- to coarse-grained porphyritic biotite-hornblende quartz monzonite. Large phenocyrsts of pink, blocky, Carlsbad-twinned microcline microperthite are common in the rock. The Eolus Granite at Mountain View Crest (fig. 2) and southwestward is granodiorite, and west of Vallecito Creek (fig. 2) it is biotite-hornblende quartz diorite. Pegmatitic and aplitic dikes and small mafic dikes locally transect the Eolus Granite.

A stock of Trimble Granite of about 5 square miles in extent intrudes the Eolus Granite batholith in Vallecito Basin, East Silver Mesa, Missouri Gulch, and from Florida Mountain to Castilleia Lake 
(pl. 1). The contact with the Eolus Granite is very sharp, but on the southwest side of the Trimble stock numerous apophyses project into the Eolus. Trimble Granite is a pale-pink to light-brick-red fine- to medium-grained porphyritic biotite granite. Phenocrysts of blocky to tabular microcline are common. Plagioclase, biotite, and opaque oxides typically are altered in varying degrees. The chemical composition of the rock is very similar to that of the biotite granite of the Eolus. Generally the Trimble is readily distinguished from the Eolus by its finer grain size.
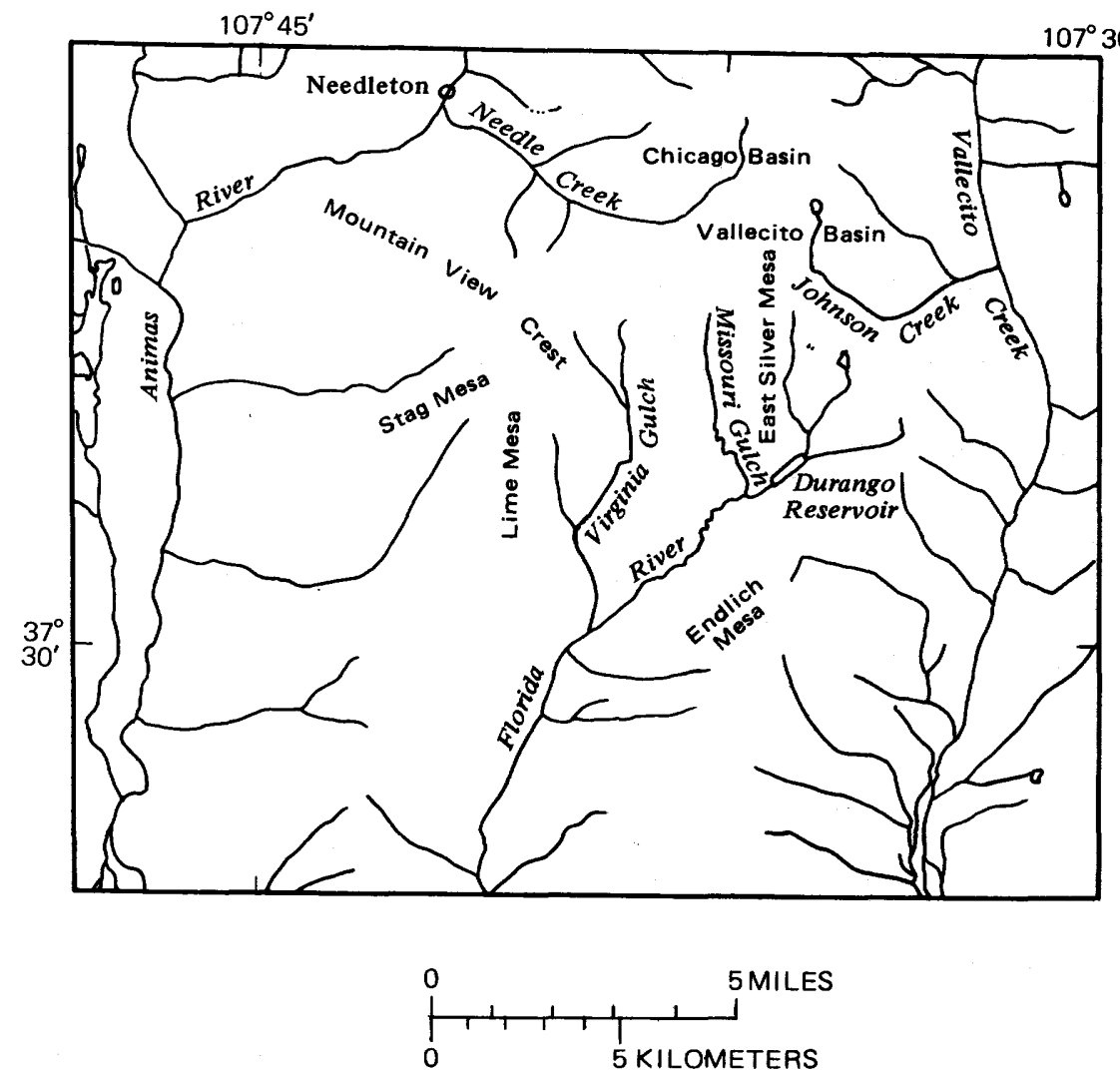

FiguRE 2.-Drainage map of the southern Needle Mountains. Drainage modified from A.M.S. 1:250,000 Durango, 1966.

\section{PALEOZOIC ROCKS}

Cambrian, Devonian, and Pennsylvanian strata crop out in the southern and southwestern parts of the district, where they dip gently southward to southwestward (Cross and others, 1905). These rocks are best exposed around the headwaters of Virginia Gulch, along 
Mountain View Crest, on Lime Mesa, and on Stag Mesa (pl. 1). The sedimentary units consist of the Cambrian Ignacio Quartzite, Devonian Elbert Formation and Ouray Limestone, and Pennsylvanian Molas and Hermosa Formations. They were deposited on a planed erosional surface of Precambrian crystalline rocks and were subsequently domed or tilted by regional forces. The Paleozoic rocks were described in some detail by Cross, Howe, Irving, and Emmons (1905, p. 3-6).

\section{TERTIARY ROCKS}

The age of the Chicago Basin stock has been determined by Charles W. Naeser (oral commun., 1975) by fission track methods using zircons from two samples, one from the older intrusive body and one from the younger. The data established for the older intrusive body (a somewhat altered porphyry) is $9.0 \pm 0.9 \mathrm{~m}$.y.; the date for the younger body (a fresh rhyolite porphyry) is $10.1 \pm 1.1 \mathrm{~m} . \mathrm{y}$. The apparent disparity between the two dates is well within the analytical error. The rhyolitic body is inferred to be younger by virtue of crosscutting relationships; but clearly, the time elapsed between the two intrusive events was short.

The stock is about 2,600 feet wide and 3,500 feet long and is composed of two major intrusive bodies. The older intrusive body is horseshoe shaped in map view and consists mainly of granite porphyries. The younger, oval-shaped body consists of rhyolite porphyry, and it intrudes the granite porphyries in the central and south-central parts of the stock. A small dike of less silicic rock transects both bodies.

\section{OLDER INTRUSIVE BODY AND RELATED ROGKS}

The older intrusive body is a subcircular mass of porphyritic to microcrystalline rock that is surrounded by Eolus Granite. The contact with the Eolus Granite is well exposed on the northwestern and eastern sides of the older intrusive body where it is sharp and steeply inclined. The contact on the northern and western sides is under soil and forest cover and its position was inferred. On the south and east the contact is generally well exposed but irregular. A few narrow dikes of older porphyry radiate outward from the older body and appear to have localized some veins. Neither the dikes nor the veins appear to transect the older body.

The older body consists of at least two gradational types of porphyry. The rock near the contact has few rounded quartz phenocrysts, an aphanitic or microcrystalline groundmass, and local flow structure, whereas toward the interior the rock has more abundant rounded quartz phenocrysts, a fine-grained or saccharoidal groundmass, and no apparent flow structure. At one place near the eastern side of the 
older body the rock has conspicuous contorted flow structure. Locally the rock ranges from nonporphyritic to coarsely porphyritic. The general appearance of the body is that of a finer grained shell surrounding a coarser grained core.

The older intrusive rocks are altered wherever they crop out. As seen microscopically, the altered rocks range from fine-grained aggregates of quartz with lacy networks of sericite to coarser grained aggregates of quartz and sericite containing abundant rounded quartz phenocrysts and abundant pockets of sericite. The coarser grained rocks generally have a relict micrographic texture similar to that of micropegmatite. Most quartz phenocrysts are partly resorbed and show unit to wavy to nearly mosaic extinction. The sericite pockets contain high-birefringent and low-birefringent sericite and local kaolinite or dickite.

Inclusions of least altered older coarse porphyry occur in the younger intrusive body along its eastern contact with the older intrusive body. As seen microscopically, the inclusions consist of anhedral quartz and euhedral to subhedral sanidine phenocrysts set in a fine-grained micrographic groundmass of quartz and alkali feldspar. The sanidine is optically biaxial negative with visually estimated optic axial angle $(2 \mathrm{~V})$ of $15^{\circ}-25^{\circ}$. Some sanidine phenocrysts contain sodic plagioclase in irregular patches and stringers suggestive of replacement perthite. The irregular distribution of plagioclase among sanidine phenocrysts also suggests a replacement origin rather than exsolution. The plagioclase is optically continuous within sanidine phenocrysts and shows fine periclinelike twinning. Sanidine is everywhere heavily clouded with minute inclusions, but the plagioclase is relatively clear. No biotite, primary muscovite, hornblende, or pyroxene was seen in any of the samples.

Compositionally and texturally the older intrusive rocks are granite porphyries or quartz porphyries. Modal analyses (volume percent) of two of the least altered porphyry inclusions taken from separate localities are given in table 1. Rapid rock analyses of the inclusions and of two least altered drill-core samples are given in table 2. The analyzed rocks are conspicuously high in $\mathrm{K}_{2} \mathrm{O}$ and $\mathrm{SiO}_{2}$ and low in $\mathrm{Al}_{2} \mathrm{O}_{3}, \mathrm{Fe}_{2} \mathrm{O}_{3}, \mathrm{FeO}, \mathrm{MgO}$, and $\mathrm{CaO}$ compared with Daly's average granite ( Daly and others, 1942 , p. 2). The $\mathrm{K}_{2} \mathrm{O}$ analyses given in table 2 are probably reliable because staining techniques indicate the rocks are very rich in potassium feldspar.

Altered brecciated rocks occur locally throughout the older intrusive body. Perhaps the most notable feature of these brecciated rocks is the presence of small angular fragments of quartz. As seen microscopically, the rocks consist of nonresorbed quartz fragments of diverse sizes set in a fine-grained aggregate of quartz and sericite. The 


\section{0}

GEOLOGY AND MINERAL DEPOSITS, NEEDLE MOUNTAINS DISTRICT

TABLE 1. - Modal analyses (volume percent) of least altered rock samples of the Chicago Basin stock

[Leaders indicate mineral not seen as separate phenocrysts. $P$, mineral present but not encountered in point counts]

\begin{tabular}{|c|c|c|c|c|c|c|c|c|c|c|c|}
\hline $\begin{array}{c}\text { Intrusive } \\
\text { body }\end{array}$ & $\begin{array}{c}\text { Sample } \\
\text { No. } \\
\text { CB- }\end{array}$ & Matrix & $\begin{array}{l}\text { Total } \\
\text { pheno- } \\
\text { crysts }\end{array}$ & $\begin{array}{l}\text { Sani- } \\
\text { dine }\end{array}$ & $\begin{array}{c}\text { Plagio- } \\
\text { clase }\end{array}$ & Quartz & Biotite & $\begin{array}{c}\text { Pyrox- } \\
\text { ene }\end{array}$ & Sphene & $\begin{array}{c}\text { Opaque } \\
\text { minerals }\end{array}$ & $\begin{array}{c}\text { Total } \\
\text { point } \\
\text { counts }\end{array}$ \\
\hline Older ... & ${ }^{1125 a}$ & 66 & 34 & 25 & $\ldots$ & 9 & $\ldots$ & $\ldots$ & $\cdots$ & $\mathbf{P}$ & 1,600 \\
\hline Older & ${ }^{2} 185 b$ & 65 & 35 & 29 & $\ldots$ & 5 & $\ldots$ & . & $\ldots$ & $<1$ & 1,800 \\
\hline Younger & 27 & 69 & 31 & 19 & 8 & 4 & $<1$ & $\ldots$ & $<1$ & $<1$ & 2,000 \\
\hline Younger & 135 & 71 & 29 & 20 & 3 & 5 & $<1$ & $\ldots$ & $<1$ & $<1$ & 2,000 \\
\hline Younger . & $185 a$ & 74 & 26 & 14 & 7 & 5 & $<1$ & $\cdots$ & $<1$ & $<1$ & 2,000 \\
\hline Dike .... & ${ }^{3} 136$ & 90 & 10 & 3 & 2 & 4 & $\ldots$ & 1 & $\ldots$ & $<1$ & 1,600 \\
\hline
\end{tabular}

${ }^{1}$ Matrix of sample contains 42 percent alkali feldspar, <1 percent plagioclase, and 24 percent quartz of total rock. ${ }^{2}$ Matrix of sample contains 41 percent alkali feldspar, $<1$ percent plagioclase, and 24 percent quartz of total rock. ${ }^{3}$ Included in matrix count are 6 percent calcite and at least 1 percent chlorite. Some calcite has replaced former phenocrysts of probable plagioclase; hence, original plagioclase was probably equal to or in excess of sanidine.

TABLE 2. - Rapid rock analyses (in percent) of least altered samples of the Chicago Basin stock

[Analyst8: Lowell Artis, S. D. Botts, G. W. Chloe, Paul Elmore, J. L. Glenn, James Kelsey, and Hezekiah Smith]

\begin{tabular}{|c|c|c|c|c|c|c|c|}
\hline \multirow[b]{3}{*}{ Sample CB- $\cdots \cdots \cdots$} & \multicolumn{7}{|c|}{ Body } \\
\hline & \multicolumn{4}{|c|}{ Older } & \multicolumn{2}{|c|}{ Younger } & \multirow{2}{*}{$\begin{array}{r}\text { Dike } \\
136 \\
\end{array}$} \\
\hline & $1 \mathrm{a}$ & $1 \mathrm{~b}$ & $125 \mathrm{a}$ & $185 \mathrm{~b}$ & 27 & $185 \mathrm{a}$ & \\
\hline$\ldots \ldots \ldots \ldots$ & 76.6 & 78.2 & 76.5 & 76.4 & 73.5 & 74.3 & 54.4 \\
\hline $\mathrm{Al}_{2} \mathrm{O}_{3} \ldots \ldots \ldots \ldots$ & 12.2 & 11.5 & 12.2 & 12.5 & 14.2 & 13.6 & 12.3 \\
\hline $\mathrm{Fe}_{2} \mathrm{O}_{3} \ldots \ldots \ldots \ldots$ & .39 & .26 & .06 & .20 & 1.1 & 1 & 3.5 \\
\hline $\mathrm{FeO} \ldots \ldots \ldots \ldots$ & .24 & .28 & .16 & .12 & .32 & .40 & 3.5 \\
\hline MgO $\ldots . . \ldots \ldots$ & .15 & .07 & .06 & .07 & .18 & .31 & 5.1 \\
\hline $\mathrm{CaO} \ldots \ldots \ldots \ldots$ & .09 & .18 & .08 & .02 & .30 & .40 & 7 \\
\hline $\mathrm{Na}_{2} \mathrm{O} \ldots \ldots \ldots \ldots$ & 1.0 & 1.1 & 1.8 & 2.8 & 2.4 & 2.3 & 2.2 \\
\hline $\mathrm{K}_{2} \mathbf{O} \ldots \ldots \ldots \ldots$ & 6.7 & 7.1 & 7.3 & 6.3 & 5.2 & 5.1 & 3.2 \\
\hline $\mathrm{H}_{2} \mathrm{O}-\ldots \ldots \ldots \ldots$ & .17 & .13 & .00 & .00 & .29 & .51 & .98 \\
\hline $\mathrm{H}_{2} \mathrm{O}+\ldots \ldots \ldots \ldots$ & 1.8 & 1.0 & 1.3 & .63 & 1.3 & 1.5 & 2.7 \\
\hline $\mathrm{TiO}_{2} \ldots \ldots \ldots \ldots$ & .15 & .13 & .12 & .15 & .27 & .24 & 1.4 \\
\hline $\mathrm{P}_{2} \mathrm{O}_{5} \ldots \ldots \ldots \ldots$ & .00 & .00 & .00 & .00 & .03 & .06 & .55 \\
\hline MnO $\ldots \ldots \ldots \ldots$ & .00 & .02 & .02 & .00 & .05 & .02 & .26 \\
\hline $\mathrm{CO}_{2} \ldots \ldots \ldots \ldots$ & .05 & .06 & $<.05$ & $<.05$ & $<.05$ & .08 & 2.8 \\
\hline Total ....... & 99.54 & 100.03 & 99.60 & 99.19 & 99.14 & 99.82 & 99.89 \\
\hline
\end{tabular}

quartz fragments are generally finely crackled and may be single grains with wavy extinction or aggregates of smaller grains with mosaic extinction. Pockets of sericite and local kaolinite, in both regular and irregular patches, are sparse to moderately abundant. Occasional large flakes of bent and broken muscovite are also present. A few samples contain discrete fragments of porphyry or Eolus Granite. 
A distinctive mass of breccia containing highly altered rock fragments more than 1 inch across occurs in the northwestern part of the older intrusive body. Fresh-appearing brecciated rocks were not found. Whether these rocks represent breccia pipes or were formed by shearing is not known.

Large masses of conglomeratic quartzite breccia as much as several feet across are exposed in the southeastern part of the older intrusive body. Some of the masses may be considerably larger because outcrops are obscured by soil cover. The rock consists of well-rounded to angular fragments of quartzite ranging in size from tiny grains to cobbles several inches across set in a matrix resembling the altered brecciated rocks described previously. Quartzite fragments are the most abundant, but other unidentified rock fragments are also present. Cross, Howe, Irving, and Emmons (1905, p. 8-9) believed that these rocks were derived from the basal conglomerates of the Precambrian $\mathrm{X}$ and $Y$ Uncompahgre Formation and were rafted up from unknown depth during intrusion of the host porphyry body. However, it seems tenuous to project the Uncompahgre Formation beneath the Eolus Granite batholith, and a source from above appears more likely. Furthermore, the rocks more closely resemble the basal conglomerates of the Cambrian Ignacio Quartzite than other conglomerates in the Needle Mountains (Fred Barker and W. J. Hail, Jr., U.S. Geol. Survey, oral commun., 1968). Projection of the Ignacio Quartzite from the nearest outcrops to the southwest over the intrusive body suggests that the quartzite dropped more than 2,000 feet down into an intrusive conduit. These observations suggest that at least part of the Paleozoic sedimentary section was in place over the site of the older intrusive body at the time of emplacement, and that the present level of exposure is at least half a mile below the original land surface. The quartzite breccia suggests that breccia pipes may be present, but none were seen within the areas of limited exposures.

All exposed older intrusive rocks are thoroughly fractured, silicified, sericitized, and pyritized to various degrees, and many of the rocks are argillized. The rocks are brightly colored in various shades of yellow, brown, red, or bluish gray. Sulfides are sparsely disseminated through the rocks and locally concentrated in microfractures and quartz veinlets.

\section{YOUNGER INTRUSIVE BODY}

The younger intrusive body is an elliptical mass of porphyritic rock that is mostly surrounded by the older intrusive body. The contact with the older intrusive body is sharp and dips inward $75^{\circ}-80^{\circ}$ on the northern and eastern sides. Numerous inclusions of the older granite porphyry occur just within the eastern margin of the elliptical porphy- 
ry body, establishing the relative ages of the two porphyries. The inclusions, which are commonly 2-5 inches in diameter, are the least altered samples of older porphyry found in the stock. Small bodies of younger porphyry crop out in the northwestern part of the older intrusive body, but were not seen elsewhere. Generally the smaller bodies are highly altered and thus may be more widespread.

The younger body is a moderately homogeneous rhyolite porphyry that consists of strongly resorbed quartz, feldspar, and biotite phenocrysts set in an aphanitic or microcrystalline groundmass. Along the southeastern margin of the body, in the area containing inclusions of older porphyry, the rhyolite porphyry has prominent flow structure with flow layers rudely parallel to the contact with the older body.

As seen microscopically, the rock consists of strongly resorbed quartz, perthitic sanidine, sodic plagioclase, biotite, and sphene phenocrysts set in a nearly aphanitic flow-structured groundmass. Plagioclase is variably altered to low-birefringent sericite or hydromica. Biotite is altered to chlorite, rutile, and sericite or hydromica. The former presence of sphene is inferred from elongate diamondshaped outlines of opaque or semiopaque material. Modal analyses (volume percent) of least altered samples of rhyolite porphyry are given in table 1.

Nearly all sanidine phenocrysts contain irregular intergrowths of plagioclase. The plagioclase is mostly untwinned, but also shows periclinelike twinning. Optically the sanidine is the same as in older intrusive rocks. The feldspar intergrowths may be exsolution perthites in part, but much of the plagioclase irregularly veins sanidine, and some plagioclase is clearly fracture controlled and seems best interpreted as being of replacement origin. In samples where plagioclase phenocrysts are intergrown with pseudoperthitic sanidine phenocrysts, the plagioclase phenocrysts are altered but the plagioclase phase of the pseudoperthite is not. This observation suggests that the plagioclase phenocrysts are more calcic than the plagioclase intergrowths in sanidine or that alteration preceded or was concurrent with development of the intergrowths.

Rapid rock analyses of least altered samples of younger porphyry are given in table 2 . The analyses confirm the rhyolitic composition of the rocks; any discrepancies from typical rhyolite may be attributed to alteration of the samples. If the rocks had been albitized, as microscopic evidence suggests, the original rocks would have been more potassic. The analyses in table 2 indicate that younger intrusive rocks are somewhat less silicic and potassic than older intrusive rocks and that they contain relatively more iron and calcium.

Younger intrusive rocks are weakly fractured and generally much 
less intensely altered than older intrusive rocks, and the alteration and mineralization of older intrusive rocks probably took place before the younger intrusive body was emplaced. The alteration of younger intrusive rocks ranges from incipient breakdown of feldspar and biotite to complete destruction of primary aluminosilicates near the periphery of the younger body. The younger rocks are yellowish brown, greenish gray, or nearly white.

\section{LATE DIKE}

A small dark-green dike transects the eastern contact between the older and younger porphyry bodies and has sharp contacts with each. The dike is as much as 20 feet wide in the older body and pinches out to the west in the younger body. The dike rock consists of sparse phenocrysts of quartz, feldspar, and pyroxene set in a finely crystalline or aphanitic groundmass.

As seen microscopically, the rock consists of rounded resorbed quartz, corrosion-rimmed sanidine, calcitized plagioclase, and chloritized diopside phenocrysts set in a fine-grained felted groundmass of feldspar and chloritized clinopyroxene. It also contains calcite in polygonal, lathlike, and semispherical masses. A modal analysis (table 1) and rapid rock analysis (table 2) indicate that the dike rock is significantly less silicic than other rocks in the stock. A spectrographic analysis of the rock shows significant amounts of Co (30 ppm), Cr (300 ppm), and $\mathrm{Ni}(100 \mathrm{ppm})$, which are characteristic mafic affinities.

This small dike is probably composed of altered mafic rock.

STRUCTURAL SUMMARY

The structural setting of the district was investigated by means of aerial photograph interpretation and field mapping. Structural elements were not studied in detail and conclusions presented here are preliminary and tentative.

Precambrian granites are regionally highly fractured, and the resulting structural grain is readily seen on aerial photographs. Most of the fractures are nearly north trending or east trending and are steeply dipping to vertical. As the fractures do not transect Paleozoic sedimentary outliers, they probably were caused by Precambrian deformation.

Radial fractures extend outward from the Chicago Basin stock and were doubtless caused by forces attending emplacement of the stock. The Precambrian granites are also cut by nearly horizontal fractures similar to those found in exfoliation domes. These fractures have resulted from regional uplift of the Needle Mountains, local upwarp during intrusion of the Chicago Basin stock, or erosional unloading.

An east-trending vertical fracture of unknown displacement tran- 
sects Eolus Granite from New York Gulch to just north of the Chicago Basin stock (pl. 1). Rudely paralleling the fracture less than 2 miles south is a zone of fractures extending from southeast of Emerald Lake eastward across the headwaters of Virginia Gulch and Missouri Gulch (pl. 1). The mass of rock between the structures may be an uplifted or downdropped block, resulting from intrusion of the Chicago Basin stock.

Other fractures that are partly discordant with the regional pattern are best developed on the mesas in the southern part of the district (pl. 1). Some of these fractures displace Paleozoic sedimentary rocks, indicating late Paleozoic or post-Paleozoic faulting. A possible interpretation is that the locus of intrusion of the Chicago Basin stock is the intersection of the generally north trending fractures with easttrending fractures.

\section{ALTERED AND MINERALIZED ROCKS}

The mineralogy and distribution of alteration minerals from the Chicago Basin stock have been determined, and have been related to local geology. The chemical compositions of altered rocks were established and compared with compositions of nearly fresh equivalents by means of AKF compatibility diagrams. Minerals from veins surrounding the stock were identified and paragenetic relations determined. Many rock samples taken from the stock, the surrounding Precambrian granite, and from veins and fracture zones were analyzed geochemically, and the geochemical anomalies measured have been related to mineralogic and geologic features.

\section{SAMPLING AND ANALYTICAL TECHNIQUES}

Most of the samples from the Chicago Basin stock were taken from outcrops along three gullies that drain northwest to Needle Creek. Sample density is not uniform over the stock but is representative of the available outcrops. Rocks in the stock were sampled without regard to visible evidence of mineralization. Therefore, the geochemical data for these samples should represent fairly the general distribution of metals at the surface within the limits of the analytical techniques used.

Samples selected for alteration studies of the older intrusive body contained small pockets of whitish clay-mica which could generally be attributed to alteration of feldspar phenocrysts. Samples taken from the younger intrusive body contained greenish-gray or white alteration minerals pseudomorphic after feldspar phenocrysts. The alteration minerals were hand-separated from the rocks with a needle-tipped probe and then were powdered. All samples were back-loaded into standard mounts to minimize the effects of preferred orientation. 
Standard X-ray diffractometer techniques using Ni-filtered Cu-radiation were used to identify the minerals.

Sampling of veins and fracture zones was guided by an attempt for broad coverage and was not systematic. Most of the samples were taken from mine dumps in order to obtain samples of the subsurface sulfide-rich portions of veins. Surface samples of altered wallrock and vein material were also taken. The main purpose of the sampling was to obtain geochemical information for the entire district.

All samples were submitted to the U.S. Geological Survey laboratories for semiquantitative spectrographic analyses, and most were also submitted for chemical analyses for $\mathrm{Au}, \mathrm{Cu}, \mathrm{Pb}$, and $\mathrm{Zn}$ and some for $\mathrm{Mo}, \mathrm{Sb}, \mathrm{As}$, and $\mathrm{Hg}$. Some of the elements were analyzed by colorimetric chemical methods and some by atomic absorption spectrophotometric techniques. A mercury vapor detector was used to analyze for mercury. Geochemical data are not tabulated in this report because of some inconsistencies in results by different analytical methods, but general metal distributions are described. The analytical data are presented in another report (Steven and others, 1969, table 10, p. F158-F167); the same sample numbers are used in both reports.

\section{CHICAGO BASIN STOCK}

Within the Chicago Basin stock rocks are intensely sericitized in most of the western part of the older intrusive body and are less intensely sericitized in the eastern part. The intensity of sericitic alteration of the rocks is based on identification of polytypes of sericite having different energy requirements. Kaolinite is widely but irregularly distributed in older rocks, but some of it is probably of supergene origin. Brecciated rocks are intensely argillized locally on the eastern side of the older body, where dickite and pyrophyllite are the only alteration minerals identified. Anomalous amounts of $\mathrm{Ag}, \mathrm{As}$, $\mathrm{Au}, \mathrm{Cu}, \mathrm{Mo}, \mathrm{Pb}, \mathrm{Sb}$, and $\mathrm{Sn}$, and perhaps $\mathrm{Bi}$ and $\mathrm{Zn}$, were detected geochemically. Some of the strongest metal anomalies coincide with the western area of most intensely sericitized rocks.

Rocks in the older intrusive body were probably altered before the younger intrusive body was emplaced, because completely altered older rocks abut relatively unaltered younger rocks along the contact between the two bodies. The presence of $2 M$ sericite is a characteristic of older intrusive rocks, but it was not found in younger intrusive rocks even near the contact.

Most of the rocks taken from the younger intrusive body in the stock are irregularly and weakly sericitized and chloritized. Locally, rocks from the periphery of the younger body are highly argillized. Anomalous amounts of $\mathrm{Ag}, \mathrm{Mo}, \mathrm{Pb}$, or $\mathrm{Zn}$ were detected geochemically 
in a few samples of younger rock, but generally the samples were devoid of anomalous metal content.

ALTERATION MINERALS OF OLDER INTRUSIVE ROCKS

Alteration has obscured the primary mineralogy of older intrusive rocks. The rocks are now quartz-sericite or quartz-sericite-kaolinite assemblages with variable amounts of pyrite.

The general term "sericite" is used in this report for all fine-grained muscovitelike minerals that give reasonably sharp X-ray diffraction profiles and that show no evidence of structural mixed layering. In this study it was not possible to prepare sufficient quantities of uncontaminated mineral separates of the clay-micas in order to obtain reliable compositional data. Therefore, precise terminology of the claymicas, which is dependent on a combination of results from X-ray diffraction studies and chemical analyses of carefully separated mineral phases, is not warranted here.

Wherever possible, sericite polytypes were differentiated according to the work of Yoder and Eugster (1955). Hence, $1 M d$ sericite indicates a single-layered monoclinic disordered muscovite structure; $1 M$ sericite indicates a single-layered monoclinic ordered muscovite structure; $2 M$ sericite indicates a double-layered monoclinic ordered muscovite structure. Another polytype, the $3 T$, or triple-layered triclinic structure, was not found in any sericites in this study. Where more than one structural type was identified in a sample, the relative proportions of each are indicated (that is, $1 M>2 M, 2 M>1 M$, etc.). In general, the $2 M$ polytype characterizes more intense conditions of alteration than the $1 M d$ or $1 M$ polytypes. Yoder and Eugster (1955) found experimentally that a transition from the $1 M$ to the $2 M$ structure takes place between $200^{\circ} \mathrm{C}$ and $350^{\circ} \mathrm{C}$ at $15,000 \mathrm{lb} / \mathrm{in}^{2}$ total water pressure. Since the $2 M$ polytype is more stable at higher temperatures than the $1 M$ polytype, thermal zoning may be indicated by the distribution of these polytypes in a sericitized body.

The term "kaolinite" is used in this report for both kaolinite and dickite because sericite interferes with discriminating between the kaolinite polymorphs by X-ray diffraction methods. Where sericite was absent, the polymorphs were differentiated.

The altered rock sample localities and the alteration mineral assemblage identified in each sample are shown in figure 3. A detailed description of the alteration minerals in individual samples is given in table 3. Most of the rocks from the west side of the older body contain $2 M$ sericite with little or no $1 M$ polytype. Rocks from the east side of the body contain both polytypes of sericite, usually with $2 M$ sericite in excess of $1 M$ sericite. In the southeastern part of the west half of the older body the rocks contain predominantly $1 M$ sericite. Kaolinite or dickite was found in variable amounts in many samples. A dickite- 


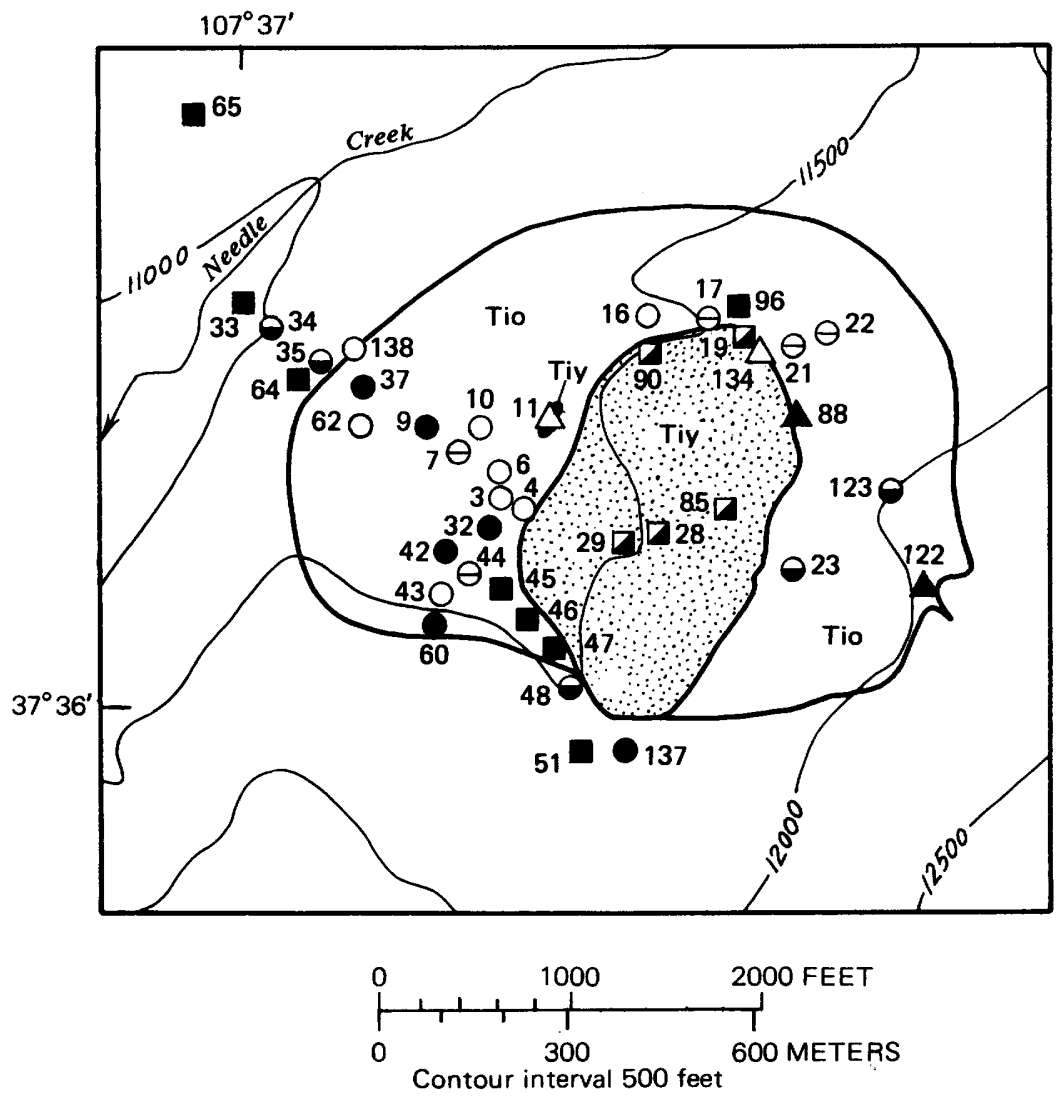

EXPLANATION

- Predominantly $2 \mathrm{M}$ sericite

O Predominantly $2 \mathrm{M}$ sericite; kaolinite variable

- 2M and $1 \mathrm{M}$ sericite

$\Theta 2 \mathrm{M}$ and $1 \mathrm{M}$ sericite; kaolinite variable

- Predominantly $1 \mathrm{M}$ sericite

1Md sericite; chlorite variable

$\triangle$ Dickite

$\Delta$ Pyrophyllite and dickite

FIGURE 3.-Map of the Chicago Basin stock showing collection localities for altered rock samples and their alteration mineral assemblages. Tio, older intrusive body; Tiy, younger intrusive body. (All samples have CB-prefixes, deleted here for brevity.)

pyrophyllite assemblage was found in only two samples, both from the east side of the older body. The alteration minerals replacing feldspar in samples of Eolus Granite taken from just outside the older body are both $1 M$ and $2 M$ sericite. 
TABLE 3. - Alteration minerals in samples from the Chicago Basin stock and immediate vicinity

\begin{tabular}{|c|c|c|}
\hline $\begin{array}{c}\text { Sample } \\
\text { No. } \\
\text { CB- }\end{array}$ & $\begin{array}{c}\text { Intrusive } \\
\text { body }\end{array}$ & $\begin{array}{l}\text { Alteration } \\
\text { minerals }\end{array}$ \\
\hline 3 & Older & $2 M$ sericite, kaolinite, quartz, tr. pyrite. \\
\hline 4 & $\ldots$ do $\ldots \ldots$ & $2 M$ sericite, dickite, quartz. \\
\hline 6 & $\ldots$ do $\ldots . .$. & $2 M$ sericite, kaolinite, quartz, pyrite. \\
\hline 7 & $\ldots$ do $\ldots .$. & $2 M>1 M$ sericite, kaolinite, quartz. \\
\hline 9 & $\ldots$ do $\ldots .$. & $2 M$ sericite, quartz, pyrite. \\
\hline 10 & $\ldots$ do $\ldots .$. & $2 M$ sericite, dickite, quartz. \\
\hline 11 & Younger...... & Dickite. \\
\hline 16 & Older $\ldots . . .$. & $2 M \gg 1 M$ sericite, kaolinite, quartz, pyrite. \\
\hline 17 & $\ldots$ do $\ldots \ldots$ & $2 M>1 M$ sericite, kaolinite, quartz, pyrite. \\
\hline 19 & Younger....... & $1 M d$ sericite. \\
\hline 21 & Older $\ldots . . .$. & $2 M>1 M$ sericite, tr. kaolinite. \\
\hline 22 & $\ldots$ do $\ldots \ldots$ & $2 M>1 M$ sericite, kaolinite, quartz, tr. pyrite. \\
\hline 23 & $\ldots$ do ..... & $2 M>1 M$ sericite. \\
\hline 28 & $\ldots$ do $\ldots .$. & $1 M d$ sericite, tr. chlorite. \\
\hline 29 & $\ldots$ do $\ldots .$. & Do. \\
\hline 32 & Older $\ldots \ldots \ldots$ & $2 M$ sericite, quartz. \\
\hline 33 & Eolus Granite . & $1 M$ sericite. \\
\hline 34 & $\ldots$ do $\ldots .$. & $2 M>1 M$ sericite, pyrite. \\
\hline 35 & $\ldots$ do $\ldots \ldots$ & $2 M \cong 1 M$ sericite, pyrite. \\
\hline 37 & Older $\ldots \ldots \ldots$ & $2 M$ sericite, pyrite. \\
\hline 42 & $\ldots$ do $\ldots .$. . & $2 M \gg 1 M$ sericite, quartz, pyrite. \\
\hline 43 & $\ldots$ do $\ldots .$. & $2 M$ sericite, dickite, quartz, pyrite. \\
\hline 44 & Older ........ & $2 M>1 M$ sericite, tr. kaolinite, quartz, pyrite. \\
\hline $45 b$ & $\ldots$ do $\ldots .$. & $1 M>2 M$ sericite, quartz, pyrite. \\
\hline 46 & $\ldots$ do $\ldots \ldots$ & $1 M \gg 2 M$ sericite, pyrite. \\
\hline 47 & $\ldots$ do $\ldots \ldots$ & $1 M>2 M$ sericite, quartz, pyrite. \\
\hline 48 & Eolus Granite . & $2 M \geqslant 1 M$ sericite, pyrite. \\
\hline 51 & $\ldots$ do $\ldots \ldots$ & $1 M>2 M$ sericite \\
\hline 60 & Older $\ldots \ldots \ldots$ & $2 M$ sericite, quartz. \\
\hline 62 & $\ldots$ do $\ldots .$. & $2 M$ sericite, kaolinite, quartz, pyrite. \\
\hline 64 & Eolus Granite . & $1 M>2 M$ sericite \\
\hline 65 & $\ldots$ do $\ldots .$. & $1 M$ sericite, kaolinite. \\
\hline 85 & Younger ....... & $1 M d$ sericite, chlorite. \\
\hline 88 & Older...... & Pyrophyllite, dickite. \\
\hline 90 & Younger...... & $1 M d$ sericite, tr. chlorite. \\
\hline 96 & Older $\ldots \ldots \ldots$ & $1 M \geqslant 2 M$ sericite, dickite, pyrite. \\
\hline 122 & $\ldots$ do $\ldots \ldots$ & Pyrophyllite, dickite. \\
\hline 123 & $\ldots$ do $\ldots .$. & $2 M>1 M$ sericite, quartz. \\
\hline 134 & Younger ....... & Dickite. \\
\hline 137 & Older dike .... & $2 M$ sericite, quartz. \\
\hline 138 & Older $\ldots \ldots \ldots$ & $2 M$ sericite, kaolinite, quartz, pyrite. \\
\hline
\end{tabular}


The change from abundant $2 M$ sericite in the western part of the older body to relatively abundant $1 M$ sericite in the eastern part probably represents primary zoning. Such zoning indicates that sericitic alteration was more intense in the western part of the stock. Although the western part of the stock is somewhat more deeply eroded than the eastern part, the difference in elevation is probably insufficient to indicate increasing intensity of alteration with depth.

The development of $1 M$ sericite in the southeastern part of the west half of the older body is closely associated with shearing along a northwest-trending zone paralleling the contact with the younger intrusive body. Whether shearing took place before or after the main period of intense $2 M$ sericite alteration is not known. Therefore, the $1 M$ sericite may represent either a local departure from intense sericitic alteration or superimposed weaker alteration of a later period.

Kaolinite is widely but nonuniformly distributed in older intrusive rocks. Some samples may contain kaolinite in excess of sericite and some have virtually no kaolinite. The only consistent relations noted are that no samples contain kaolinite exclusive of other alteration minerals and that samples with sericite predominantly of the $1 M$ polytype have no significant kaolinite. Kaolinite that occurs as microscopic veinlets that transect sericite pockets is probably of supergene origin; kaolinite that occurs in sericite pockets without crosscutting relations is probably a primary alteration product.

Two samples taken from the east half of the older body, one of brecciated rock and one of conglomeratic quartzite breccia, contain dickite and pyrophyllite to the exclusion of sericite. This alteration mineral assemblage was not found in any samples of porphyry nor in samples of brecciated rock from other parts of the older body. According to Deer, Howie, and Zussman (1962, p. 117-119), various laboratory experiments on the alteration of feldspar show that pyrophyllite is generally obtained at temperatures between $300^{\circ} \mathrm{C}$ and $550^{\circ} \mathrm{C}$, provided there is insufficient aluminum to produce kaolinite. At moderate pressures and above $350^{\circ} \mathrm{C}$, pyrophyllite forms rather than kaolinite. Pyrophyllite apparently displaces sericite in the two samples taken from the eastern part of the older intrusive body. Local intense hydrolytic activity in the altering fluids would account for displacement of sericite by pyrophyllite (Hemley and Jones, 1964). If dickite and pyrophyllite, an advanced argillic alteration mineral assemblage, are generally present in brecciated rocks from the eastern part of the older body, the assemblage may outline areas where intense hydrolytic activity was localized by restrictive structures such as breccia pipes.

Samples of altered Eolus Granite taken northwest and south of the stock contain $1 M$ and $2 M$ sericite (fig. 3). A halo of sericitized granite probably surrounds the stock as a primary alteration effect. 
A sample of altered porphyry taken from a dike cutting Eolus Granite south of the Chicago Basin stock contains $2 M$ sericite exclusive of other alteration minerals (fig. 3, sample CB-137). The alteration mineralogy and microscopic appearance of the rock suggest that the dike is related to the older intrusive body. Other small dikes exposed south and southeast of the stock are similar to the one sampled.

\section{CHEMICAL COMPOSITIONS OF OLDER INTRUSIVE ROCKS}

Rapid rock analyses of altered samples representing all major rock types and alteration mineral assemblages from the older body are given in table 4. The results for the altered porphyries may be compared with results for least altered equivalents by referring to table 2 . The altered porphyries relative to their least altered equivalents are high in $\mathrm{SiO}_{2}, \mathrm{Al}_{2} \mathrm{O}_{3}$, and $\mathrm{H}_{2} \mathrm{O}$ and distinctly low in $\mathrm{Na}_{2} \mathrm{O}$ and $\mathrm{K}_{2} \mathrm{O}$. Compared with Daly's average granite (Daly and others, 1942, p. 2), all the altered rocks are high in $\mathrm{SiO}_{2}$ and $\mathrm{H}_{2} \mathrm{O}$ and low in $\mathrm{Al}_{2} \mathrm{O}_{3}, \mathrm{FeO}$, $\mathrm{MgO}, \mathrm{CaO}$, and $\mathrm{Na}_{2} \mathrm{O}$. The most pronounced chemical change produced by alteration was the relative depletion of the alkalis. Analyses of least altered porphyries, representing subsurface samples, show 6.3-7.3 percent $\mathrm{K}_{2} \mathrm{O}$ (table 2); the altered rocks generally show 3-4 percent $\mathrm{K}_{2} \mathrm{O}$ (table 4). Analyses of least altered porphyries show 1-2.8 percent $\mathrm{Na}_{2} \mathrm{O}$ (table 2); the $\mathrm{Na}_{2} \mathrm{O}$ values for altered porphyries are negligible.

The oxide components of the rapid rock analyses for all older intrusive rocks were converted to molecular percents and plotted on an AKF compatibility diagram (fig. 4). The procedure is the same as that described by Creasey (1959). The AKF diagram may be used to visualize mineralogical relations predicted by the rock analyses for least altered and altered samples. The apices of the diagram represent the critical components for silicic aluminous rocks: (A) $\mathrm{Al}_{2} \mathrm{O}_{3}-\left(\mathrm{CaO}+\mathrm{Na}_{2} \mathrm{O}+\mathrm{K}_{2} \mathrm{O}\right)$; (K) $\mathrm{K}_{2} \mathrm{O}$; and (F) $\mathrm{FeO}+\mathrm{MnO}+\mathrm{MgO}$. Argillized rocks rich in kaolinite group minerals will plot near the (A) apex of the diagram. Rocks rich in potassium feldspar or other potassic minerals will plot near the $(\mathrm{K})$ apex of the diagram. Highly sericitized rocks will plot near the muscovite join.

All the samples plot along the (AK) side of the diagram, consistent with few ferromagnesian constituents in older intrusive rocks. Least altered samples (table 2) plot near the $(K)$ apex of the diagram because of their richness in $\mathrm{K}_{2} \mathrm{O}$. Altered samples (table 4) plot near the composition of muscovite because sericite is commonly the dominant alteration product. One sample plots very near the (A) apex of the diagram (table 4, sample $\mathrm{CB}-88$ ), indicating a highly aluminous potassium-deficient mineral assemblage.

The data for least altered rocks, which plot near the (K) apex, repre- 
sent samples from the buried core of the older intrusive body. Three of the samples (CB-125a, $-185 \mathrm{~b}$, and $-1 \mathrm{~b})$ should be relatively rich in potassium feldspar. These results are compatible with abundant potassium feldspar found in the rocks. One of the samples (CB-1a) should contain relatively less potassium feldspar than the others. As seen microscopically, the sample is similar to the others except for incipient sericitization of feldspar. The AKF mineral assemblages are compatible with the minerals actually found in the rocks, illustrating the abundance of potassium silicate in the subsurface core of the older body.

TABLE 4. - Rapid rock analyses (in percent) of altered samples from the older intrusive body in the Chicago Basin stock

[Analysts: Lowell Artis, S. D. Botts, G. W. Chloe, Paul Elmore, J. L. Glenn, James Kelsey, and Hezekiah Smith. Leaders indicate no analysis]

\begin{tabular}{|c|c|c|c|c|c|c|c|c|c|c|c|}
\hline \multirow[b]{2}{*}{ Sample CB- } & \multicolumn{6}{|c|}{ Porphyritic rocks } & \multicolumn{5}{|c|}{ Brecciated rocks } \\
\hline & 7 & 17 & 32 & 38 & 63 & 123 & 21 & 21 & 37 & 46 & 88 \\
\hline $\mathrm{SiO}_{2}$ & 79.9 & 78.4 & 79.9 & 79.2 & 78.4 & 79.2 & 78.4 & 76.2 & 76.9 & 76.3 & 80.3 \\
\hline $\mathrm{Al}_{2} \mathrm{O}_{3}$. & 12.6 & 13.6 & 11.9 & 13.2 & 13.4 & 13.2 & 13.4 & 13.6 & 13.0 & 14.4 & 12.0 \\
\hline $\mathrm{Fe}_{2} \mathrm{O}_{3} \ldots$ & .40 & .56 & .94 & .52 & .66 & .14 & .57 & 2.4 & 2.3 & .47 & 1.2 \\
\hline $\mathrm{FeO}$. & .16 & .40 & .24 & .12 & .24 & .24 & .32 & .36 & .16 & .16 & .12 \\
\hline MgO & .12 & .23 & .18 & .31 & .55 & .31 & .41 & .55 & .55 & .33 & .06 \\
\hline $\mathrm{CaO}$ & .38 & .14 & .17 & .14 & .61 & .07 & .14 & .09 & .12 & .43 & .12 \\
\hline $\mathrm{Na}_{2} \mathrm{O} \ldots \ldots$ & .13 & .09 & .16 & .15 & .37 & .03 & .12 & .06 & .16 & .11 & .05 \\
\hline $\mathrm{K}_{2} \mathbf{O} \ldots \ldots$ & 3.2 & 3.9 & 3.8 & 4.0 & 3.6 & 3.8 & 3.8 & 4.0 & 3.8 & 4.0 & .61 \\
\hline $\mathrm{H}_{2} \mathrm{O}-\ldots$ & .08 & .09 & .07 & .02 & .10 & .12 & .12 & .25 & .05 & .22 & .10 \\
\hline $\mathrm{H}_{2} \mathrm{O}+\ldots \ldots$ & 2.6 & 1.8 & 1.7 & 1.8 & 1.7 & 1.7 & 2.1 & 2.0 & 1.6 & 2.3 & 2.7 \\
\hline $\mathrm{TiO}_{2}$ & .22 & .22 & .13 & .13 & .15 & .16 & .28 & .33 & .36 & .41 & .27 \\
\hline $\mathrm{P}_{2} \mathrm{O}_{5} \ldots \ldots$ & .00 & .03 & .00 & .02 & .04 & .05 & .15 & .07 & .07 & .06 & .14 \\
\hline MnO ..... & .00 & .00 & .00 & .00 & .02 & .04 & .02 & .04 & .00 & .03 & .04 \\
\hline $\mathrm{CO}_{2} \ldots$ & $<.05$ &.$<.05$ & $<.05$ & $<.05$ & $<.05$ & .05 & $<.05$ & .05 & $<.05$ & $<.05$ & $<.05$ \\
\hline $\mathbf{F} \ldots \ldots \ldots$ & $\ldots$ & $\ldots$ & $\ldots$ & $\ldots$ & $\ldots$ & $\ldots$ & $\ldots$ & $\ldots$ & $\ldots$ & $\ldots$ & .75 \\
\hline Total $\ldots$ & 99.79 & 99.46 & 99.19 & 99.61 & 99.84 & 99.11 & 99.83 & 100.00 & 99.07 & 99.22 & 98.46 \\
\hline
\end{tabular}

The results for altered samples illustrate the intense sericitic alteration of most rocks collected. The data also confirm the dominance of sericitization over kaolinization in the alteration of older rocks. One sample (CB-88) plots very near the (A) apex of the AKF diagram, predicting an argillic alteration mineral assemblage of an advanced stage. This sample of brecciated rock contains pyrophyllite and dickite to the exclusion of sericite. The AKF-predicted mineral assemblages are again compatible with the minerals actually present in the rocks.

Alteration of dikes radial to the Chicago Basin stock is similar to that in older intrusive rocks of the stock. One of the larger of these 


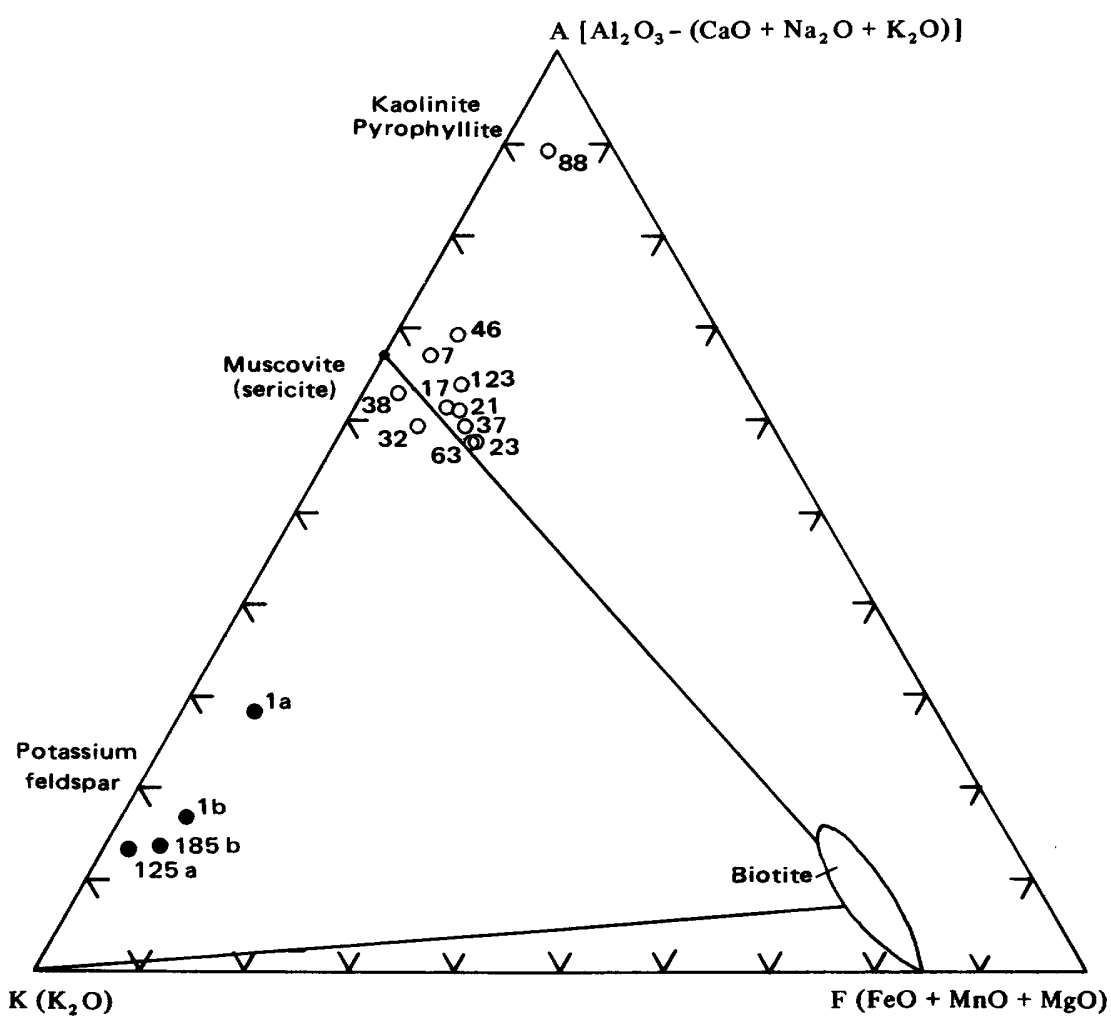

FIGURE 4.-AKF compatibility diagram for older intrusive rocks in the Chicago Basin stock. Open circle, altered rocks; closed circle, least altered rocks. (All samples have CB-prefixes, omitted here for brevity.)

dikes follows a northwest-trending fracture zone prominently flanked by intensely silicified granite in Vallecito Basin (pl. 1).

Rapid rock analyses of samples from dikes show anomalously large amounts of $\mathrm{K}_{2} \mathrm{O}$ (table 5). An AKF compatibility diagram for the dike rocks (fig. 5) is useful in comparing these rocks with those from the older intrusive body in Chicago Basin (fig. 4). For sample CB-163 (table 5), from a dike paralleling the Aztec vein in southern Chicago Basin (pl. 1); the analysis is similar to analyses for least altered samples $\mathrm{CB}-1 \mathrm{a}$ and $\mathrm{CB}-1 \mathrm{~b}$ of the older intrusive body (table 2). Samples CB-266 and CB-267b (table 5) were taken from a dike enveloped by a major altered zone in Vallecito Basin (pl. 1). Sample CB-266, from an outcrop on Columbine Pass, is a highly sericitized porphyritic rock and its analysis (table 5) is similar to the analyses for altered samples from outcrops of the older intrusive body (table 4). Except for the very low $\mathrm{Na}_{2} \mathrm{O}$ content, the analysis for sample $\mathrm{CB}-267 \mathrm{~b}$ (table 5) is similar to analyses of least altered older intrusive rocks (table 2). Sample 
CB-267b was taken from an outcrop in central Vallecito Basin, about 1,100 feet vertically lower than sample CB-266 from the same dike on Columbine Pass. Sample CB-231 is a pyrite-bearing porphyritic intrusive rock from a mine dump southwest of the main dike in Vallecito Basin. The rock is less silicic than most of the other analyzed intrusive rocks. The high $\mathrm{K}_{2} \mathrm{O}$ content of these dike rocks is similar to that in samples of the buried core of the older intrusive body in the stock represented by least altered inclusions in the younger porphyry:

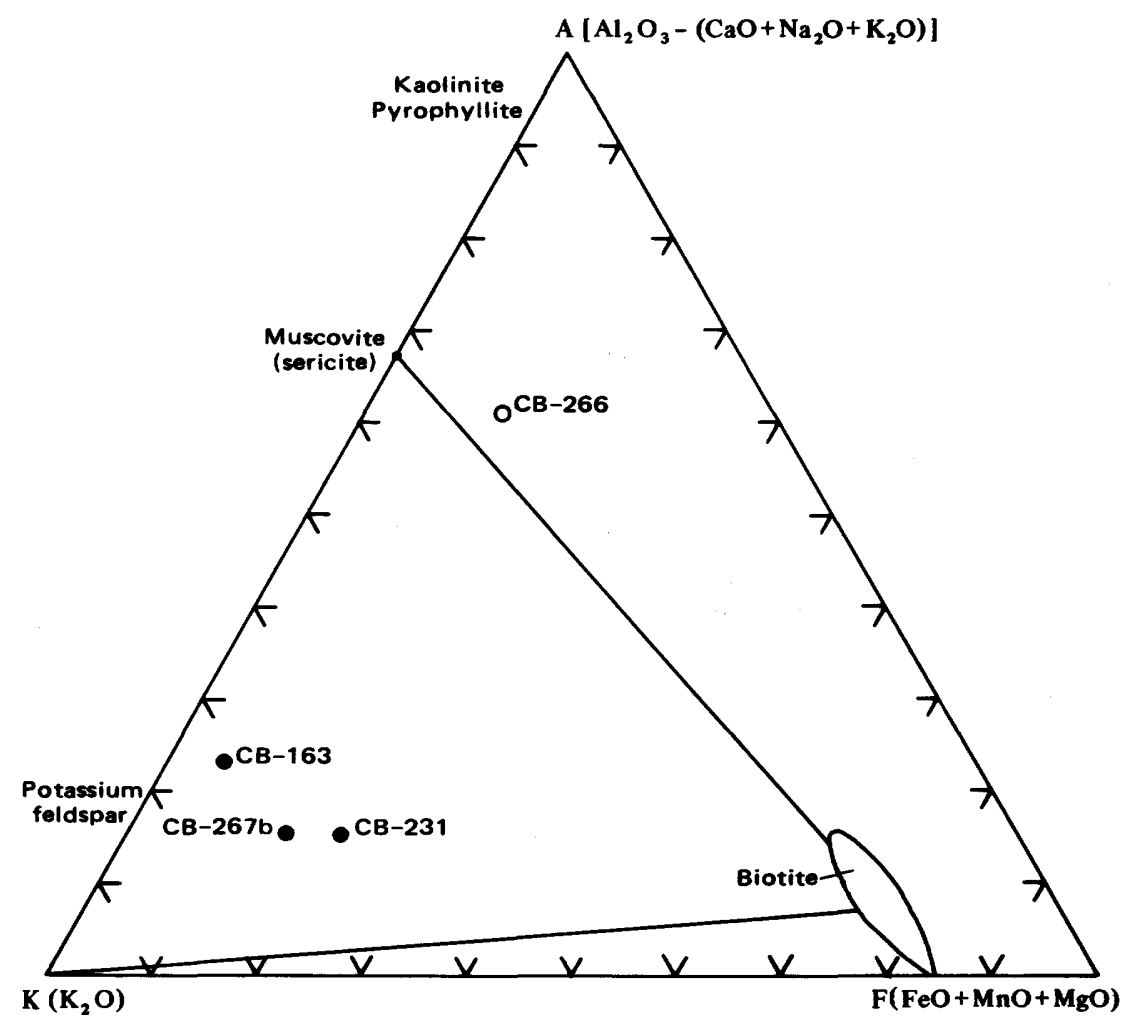

FIGURE 5.-AKF compatibility diagram for rock samples of dikes related to the older intrusive body in the Chicago Basin stock. Open circle, altered rocks; closed circle, least altered rocks.

\section{SIGNIFICANCE OF ALTERATION FEATURES}

The nearly complete alteration of older intrusive rocks at their present level of exposure indicates that abundant reactive fluids were in contact with the rocks over a significant period of time. Extensive fracturing of the older body probably allowed easy access for the fluids. The absence of less altered remnants indicates that some kind of chemical balance was approached between rocks and reactive fluids. Inasmuch as all the samples were collected at the surface, it has 
TABLE 5. - Rapid rock analyses (in percent) of samples taken from dikes related to the older intrusive body in the Chicago Basin stock [Analysts: Lowell Artis, S. D. Botts, G. W. Chloe, Paul Elmore, J. L. Glenn, James Kelsey, and Hezekiah Smith]

\begin{tabular}{|c|c|c|c|c|}
\hline Sample CB- $-\ldots \ldots \ldots \ldots \ldots$ & 163 & 231 & 266 & 267b \\
\hline $\mathrm{SiO}_{2} \ldots \ldots \ldots \ldots \ldots$ & 78.3 & 66.6 & 78.9 & 77.7 \\
\hline $\mathrm{Al}_{2} \mathrm{O}_{3} \ldots \ldots \ldots \ldots$ & 11.4 & 15.5 & 13.2 & 11.4 \\
\hline $\mathrm{Fe}_{2} \mathrm{O}_{3} \ldots \ldots \ldots \ldots$ & .54 & 2.7 & .06 & .00 \\
\hline $\mathrm{FeO} \ldots \ldots \ldots \ldots \ldots$ & .12 & .32 & .16 & .76 \\
\hline MgO ............. & .07 & .84 & .58 & .28 \\
\hline $\mathrm{CaO} \ldots \ldots \ldots \ldots$ & .13 & 1.1 & .11 & .18 \\
\hline $\mathrm{Na}_{2} \mathrm{O} \ldots \ldots \ldots \ldots$ & 1.4 & 1.7 & .00 & .18 \\
\hline $\mathrm{K}_{2} \mathbf{O} \ldots \ldots \ldots \ldots \ldots$ & 6.2 & 8.0 & 3.6 & 8.2 \\
\hline $\mathrm{H}_{2} \mathrm{O}-\ldots \ldots \ldots \ldots$ & .02 & .43 & .71 & .11 \\
\hline $\mathbf{H}_{2} \mathbf{O}+\ldots \ldots \ldots \ldots$ & .70 & 1.6 & 2.1 & 1.0 \\
\hline$\ldots \ldots \ldots \ldots \ldots$ & .07 & .64 & .37 & .13 \\
\hline $\mathrm{P}_{2} \mathrm{O}_{5} \ldots \ldots \ldots \ldots \ldots$ & .00 & .24 & .02 & .02 \\
\hline MnO $\ldots \ldots \ldots \ldots$ & .03 & .15 & .04 & .04 \\
\hline $\mathrm{CO}_{2} \ldots \ldots \ldots \ldots \ldots$ & $<.05$ & .09 & .09 & .05 \\
\hline Total $\ldots \ldots \ldots$ & 98.98 & 99.91 & 99.94 & 100.05 \\
\hline
\end{tabular}

not been possible to determine the extent or type of alteration at depth; evidence from one drill core and from inclusions of older intrusive rock in the younger intrusive body, however, suggests that the rocks are much less altered at depth.

Quartz and sericite occur throughout outcropping older intrusive rocks except in brecciated rocks from the eastern part of the older body. The sericite has different muscovite structures, or polytypes, in different parts of the older body, probably corresponding to variations in pressure and temperature of the altering fluids. The distribution of sericite polytypes indicates that sericitic alteration was most intense on the western side of the older body, but this may be partly an apparent effect because the western part of the body is more deeply eroded than the eastern part. Sericite polytypes may be similar at similar elevations in the older body. Brecciated rocks in the eastern part of the older body contain pyrophyllite instead of sericite; indicating extreme argillic alteration. The restriction of advanced argillic alteration to brecciated rocks in a local part of the older body suggests that hydrothermal solutions here were confined by restrictive structures, possibly breccia pipes.

Hydrothermal alteration of the rocks involved striking changes in $\mathrm{K}_{2} \mathrm{O}$ and $\mathrm{Na}_{2} \mathrm{O} . \mathrm{K}_{2} \mathrm{O}$ was depleted and $\mathrm{Na}_{2} \mathrm{O}$ nearly eliminted as primary feldspar was destroyed and replaced by sericite. Locally in the eastern part of the older body, alteration has nearly eliminated both $\mathrm{K}_{2} \mathrm{O}$ and $\mathrm{Na}_{2} \mathrm{O}$ as sericite was displaced by pyrophyllite, and fluorine 
was added to the rocks. Theoretically a change from potassic feldspathic rocks at depth to sericitized rocks above can result from chemical changes in a single altering solution. Reaction of an ascending altering solution with aluminous wallrock could change the composition of the solution and promote different degrees of alkali leaching at different levels in a rock mass. Hemley and Jones (1964) discussed the nature of these reactions in terms of changes in the cation $/ \mathrm{H}^{+}$activity ratios in altering solutions. Detailed subsurface data would be needed to determine whether the total alteration effect in the older intrusive body was accomplished by essentially a single hypogene solution. Available data are consistent with hydrolytic alkali leaching as the operative alteration process that affected older intrusive rocks.

\section{GEOCHEMICAL INVESTIGATIONS OF THE OLDER INTRUSIVE ROCKS}

Most older intrusive rocks in the stock contain pyrite, many contain secondary quartz, and some contain molybdenite. Pyrite is widely disseminated and concentrated along fractures. Quartz veinlets in the western part of the older body generally are less than one-fourth inch wide and crisscross one another, in some places with small displacements. Bluish-gray molybdenite flakes, most less than $1 \mathrm{~mm}$ in size, are concentrated along the walls of some veinlets. Molybdenite flakes of the same size are disseminated through pockets of alteration minerals and through the groundmass of some porphyritic rocks. A few rocks contain small amounts of chalcopyrite, galena, sphalerite, or rhodochrosite. Generally the rock constituents are highly obscured by heavy coatings of iron oxides or sulfates. Therefore, mineral appraisals based on field observations are probably unreliable.

Fifty rock samples taken from the older intrusive body were submitted for semiquantitative spectrographic analyses for 30 elements and chemical analyses for $\mathrm{Au}, \mathrm{Cu}, \mathrm{Mo}, \mathrm{Pb}, \mathrm{Zn}$, and some for $\mathrm{Sb}$. Sample localities are shown on plate 1 . The analytical data are not tabulated here but were reported by Steven, Schmitt, Sheridan, and Williams (1969, table 10, p. F158-F167). The limits of detection by different analytical methods for elements considered geochemically significant and the levels of detection considered anomalous are given in table 6. Succeeding paragraphs describe the general geochemical results.

Antimony and arsenic were detected in anomalous amounts only on the west side of the older body. High detection limits for $\mathrm{Sb}$ and As by spectrographic methods (table 6) probably obscure a wider anomalous distribution of these elements; $\mathrm{Sb}$ was detected in six samples and As was detected in seven samples. Most of the anomalous samples were taken near the intersection of three drainage cuts in the western part of the older body where $\mathrm{Cu}$ is also concentrated. The distribution of $\mathrm{Sb}$ 
TABLE 6. - Limits of detection by different analytical methods for elements considered geochemically significant and levels of concentration considered anomalous

\begin{tabular}{|c|c|c|c|c|}
\hline \multirow{3}{*}{ Element } & \multicolumn{2}{|c|}{$\begin{array}{l}\text { Detection limit } \\
\quad \text { (in ppm) }\end{array}$} & \multicolumn{2}{|c|}{$\begin{array}{l}\text { Level of concentration } \\
\text { considered anomalous } \\
\text { (in ppm) }\end{array}$} \\
\hline & \multicolumn{4}{|c|}{ Analytical method } \\
\hline & $\begin{array}{l}\text { Spectro- } \\
\text { graphic }\end{array}$ & Chemical & $\begin{array}{l}\text { Spectro- } \\
\text { graphic }\end{array}$ & Chemical \\
\hline Antimony $\ldots \ldots \ldots \ldots$ & 100 & $\ldots$ & 100 & $\ldots$ \\
\hline Arsenic $\ldots \ldots \ldots \ldots$ & 200 & $\ldots$ & 200 & $\ldots$ \\
\hline Bismuth $\ldots \ldots \ldots \ldots$ & 10 & $\ldots$ & 10 & $\ldots$ \\
\hline Copper $\ldots \ldots \ldots \ldots \ldots$ & 5 & 10 & 100 & 100 \\
\hline Gold $\ldots \ldots \ldots \ldots \ldots$ & $\mathbf{N}$ & $.02-.20$ & $\mathbf{N}$ & .20 \\
\hline Lead $\ldots \ldots \ldots \ldots \ldots$ & 10 & 25 & 100 & 100 \\
\hline Molybdenum ......... & 5 & 2 & 30 & 30 \\
\hline Silver $\ldots \ldots \ldots \ldots \ldots$ & .5 & $\ldots$ & .5 & $\ldots$ \\
\hline $\operatorname{Tin} \ldots \ldots \ldots \ldots \ldots$ & 10 & $\ldots$ & 10 & $\ldots$ \\
\hline Tungsten $\ldots \ldots \ldots \ldots$ & 50 & $\ldots$ & 50 & $\ldots$ \\
\hline Zinc $\ldots \ldots \ldots \ldots \ldots$ & 200 & 25 & 200 & 100 \\
\hline
\end{tabular}

and As in anomalous amounts roughly coincides with the distribution of intense sericitic alteration of the rocks.

Bismuth was detected by spectrographic methods, and is therefore anomalous in only two samples-one from the west side and one from the north side of the older body.

Copper in anomalous amounts was detected in samples taken from the west side of the older body - in 14 samples by spectrographic methods but in only 4 samples by chemical methods. Samples with anomalous amounts of $\mathrm{Cu}$ are concentrated near the confluence of three drainage cuts on the west side of the older body. The distribution of $\mathrm{Cu}$ in anomalous amounts roughly coincides with the distribution of most intense sericitic alteration of the rocks.

Gold was detected in many samples, but the limit of detection varied with the amount of sample available. Four samples from the west side of the older intrusive body contained highly anomalous amounts of $\mathrm{Au}$ $(\geq 0.2 \mathrm{ppm})$ by atomic absorption methods.

Lead in anomalous amounts was detected in widely distributed samples but in somewhat more samples in the western and northern parts than in the eastern and southern parts of the older body. Anomalous amounts of $\mathrm{Pb}$ were detected in 22 samples by spectrographic methods and in 11 samples by chemical methods. The distribution of $\mathrm{Pb}$ in anomalous amounts is similar to that of $\mathrm{Zn}$ in anomalous amounts, but more samples are anomalous in $\mathrm{Pb}$.

Molybdenum was detected by spectrographic methods in most of the samples collected from the older intrusive body. Thirty samples con- 
tained anomalous amounts of Mo and all were from the west side of the older body. The distribution of Mo in anomalous amounts correlates well with the distribution of $2 M$ sericite except in the southeastern part of the west side of the older body. Two areas of very high Mo content (at least $200 \mathrm{ppm}$ Mo) exist; one is near the confluence of three tributary drainages and the other is to the south. These locally concentrated anomalies are probably real because the same pattern is suggested by the distribution of $\mathrm{Cu}$ in anomalous amounts.

Silver does not appear to have the restricted distribution of $\mathrm{Cu}, \mathrm{Sb}$, and As but was widely detected over the entire intrusive body. Silver was detected in 35 samples, and any sample with detectable silver is probably anomalous. The distribution of $\mathrm{Ag}$ in anomalous amounts is similar to that of $\mathrm{Pb}$.

The distribution of samples with detectable tin is reasonably uniform on the west and north sides of the older body. All 34 samples in which tin was detected are considered anomalous. The distribution of samples with anomalous amounts of $\mathrm{Sn}$ is similar to but more restricted than the distribution of samples with anomalous amounts of $\mathrm{Pb}$. The distribution of $\mathrm{Sn}$ in anomalous amounts correlates well with the distribution of intense sericitic alteration of the rocks except in the southeastern part of the west side of the older body.

Tungsten was not detected in any sample taken from the older body; however, its high spectrographic detection limit (table 6) may mask low-level tungsten anomalies.

Zinc in anomalous amounts was found in only 2 samples by spectrographic methods but in 13 samples by chemical methods. This disparity is caused largely by significantly different detection limits for $\mathrm{Zn}$ by the two analytical methods (table 6).

An inclusion of older intrusive porphyry (pl. 1, sample CB-125) taken from the southeast margin of the younger porphyry body, not mentioned in the previous descriptions of metal distributions, contains small flakes of molybdenite along hairline fractures. Anomalously large amounts of $\mathrm{Ag}, \mathrm{As}, \mathrm{Cu}, \mathrm{Mo}, \mathrm{Pb}, \mathrm{Sb}$, and $\mathrm{Sn}$ were detected in the sample by spectrographic methods. This sample is considered especially significant because other inclusions from the same general area and to the north (pl. 1, sample CB-185b) also contain molybdenite. Although the exact source of these metallized inclusions is not known, the inclusions clearly represent a composite subsurface sample of older intrusive rock.

Twenty-five samples of altered Eolus Granite and related rocks were taken from Chicago Basin both near and at some distance from the stock. The geochemical data for these samples suggest that Ag, $\mathrm{Mo}, \mathrm{Pb}, \mathrm{Sn}$, and perhaps $\mathrm{Zn}$ are weakly anomalous. 


\section{ALTERATION MINERALS AND CHEMICAL COMPOSITIONS OF YOUNGER INTRUSIVE ROCKS}

The younger intrusive body of rhyolite porphyry is less altered than the surrounding older body. The younger rocks are generally bleached and oxidized, weakly and irregularly sericitized, selectively chloritized, and locally intensely argillized. Typically, plagioclase phenocrysts are variably altered to $1 M d$ sericite (fig. 3). Biotite is altered to chlorite, $1 M d$ or $1 M$ sericite, and rutile. Sphene and opaque oxides are largely converted to secondary oxides of iron and titanium. Rocks from the outer margin of the younger intrusive body are more completely altered. The marginal younger rocks superficially resemble older intrusive rocks.

Locally along the periphery of the younger body the rocks contain conspicuous white clay pseudomorphs after feldspar phenocrysts that readily break away from the matrix, imparting a distinctive scoriaceouslike texture to weathered surfaces. The only alteration mineral identified in these rocks is dickite. A rapid rock analysis of the intensely argillized porphyry is given in table 7 . The analytical data may be compared with data for least altered equivalents by referring to table 2. All rock analyses for younger intrusive rocks have been plotted on an AKF compatibility diagram (fig. 6) for comparison with results from older intrusive rocks.

$\mathrm{T}_{\mathrm{ABLE}}$ 7. - Rapid rock analysis (in percent) of altered sample $\mathrm{CB}-11$ a of the younger intrusive body in the Chicago Basin stock

[Analysts: Lowell Artis, S. D. Botts, G. W. Chloe, Paul Elmore, J. L. Glenn, James Kelsey, and Hezekiah Smith]

\begin{tabular}{|c|c|c|c|}
\hline $\mathrm{SiO}_{2}$ & $\ldots \ldots \ldots \ldots \ldots \ldots \ldots+77.8$ & $\mathrm{~K}_{\mathbf{2}} \mathrm{O} \quad \ldots$ & 2.6 \\
\hline $\mathrm{Al}_{2} \mathrm{O}_{3}$ & $\ldots \ldots \ldots \ldots \ldots \ldots \ldots \ldots \ldots \ldots, 14.0$ & $\ldots \ldots \ldots \ldots \ldots \ldots \ldots \ldots \ldots$ & .19 \\
\hline $\mathrm{Fe}_{2} \mathrm{O}_{3}$ & $\ldots \ldots \ldots \ldots \ldots \ldots \ldots \ldots \ldots \ldots \ldots \ldots \ldots \ldots \ldots \ldots \ldots, \quad .00$, & $\mathbf{H}_{2} \mathbf{O}+\ldots \ldots \ldots \ldots \ldots \ldots \ldots \ldots \ldots \ldots \ldots \ldots \ldots \ldots \ldots \ldots$ & 3.5 \\
\hline $\mathrm{FeO}$ & $\ldots \ldots \ldots \ldots \ldots$ & $\mathbf{T i O}_{2} \ldots \ldots \ldots \ldots \ldots \ldots \ldots \ldots \ldots \ldots \ldots \ldots \ldots$ & .30 \\
\hline MgO & $\ldots \ldots \ldots \ldots \ldots \ldots \ldots \ldots \ldots \ldots \ldots \ldots \ldots \ldots$ & 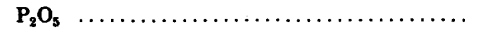 & .02 \\
\hline $\mathrm{CaO}$ & $\ldots \ldots \ldots \ldots \ldots \ldots \ldots \ldots \ldots \ldots \ldots \ldots \ldots \ldots$ & 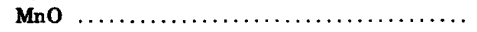 & .00 \\
\hline \multirow[t]{2}{*}{$\mathrm{Na}_{2} \mathrm{O}$} & 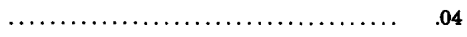 & 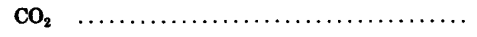 & .05 \\
\hline & & Total $\ldots \ldots \ldots \ldots \ldots \ldots \ldots \ldots \ldots \ldots \ldots$ & $\overline{99.26}$ \\
\hline
\end{tabular}

Alteration of rhyolite porphyry from the younger body has apparently proceeded toward relative enrichment of $\mathrm{SiO}_{2}$ and $\mathrm{H}_{2} \mathrm{O}$ and relative depletion of $\mathrm{Fe}_{2} \mathrm{O}_{3}, \mathrm{CaO}, \mathrm{Na}_{2} \mathrm{O}$, and $\mathrm{K}_{2} \mathrm{O}$. The AKF compatibility diagram for younger intrusive rocks (fig. 6) is significantly different from that for older intrusive rocks (fig. 4). Least altered samples of younger porphyry (samples CB-27, -185a) plot in a position intermediate between least altered older porphyries and sericitized older porphyries (fig. 4). This relation is entirely consistent with the incomplete weak sericitization of younger intrusive rocks. A sample of highly argillized younger porphyry (sample CB-11a) plots in a posi- 


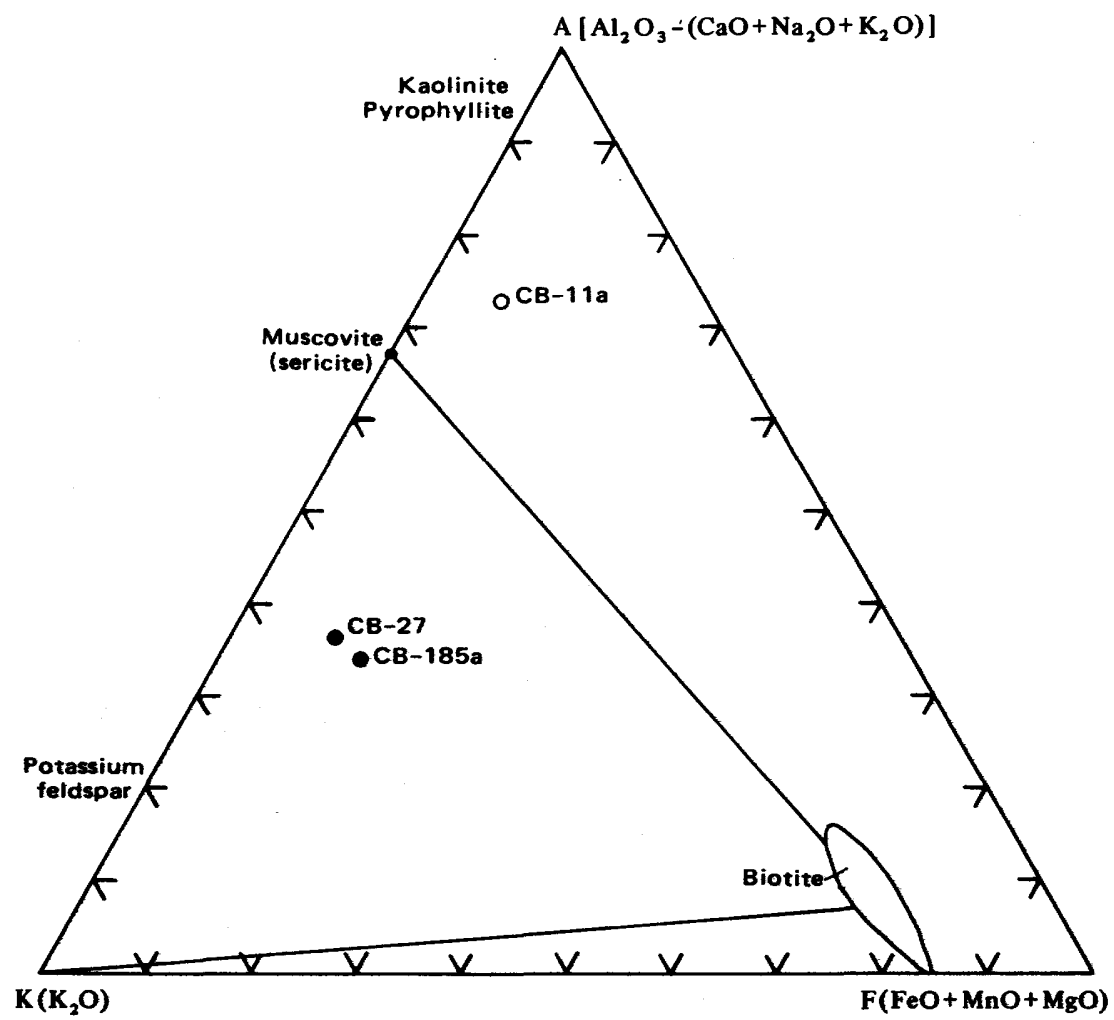

Figure 6.-AKF compatibility diagram for samples of younger intrusive rocks from the Chicago Basin stock. Open circle, altered rocks; closed circle, least altered rocks.

tion intermediate between sericitized older rocks and a breccia with an advanced argillic alteration mineral assemblage (fig. 4, sample CB-88). Sample CB-11a (fig. 6) plots in a position entirely consistent with normal argillic alteration.

Some of the gaps in the AKF diagrams for older and younger rocks would probably be filled if more samples were available, especially subsurface samples. The major difference between alteration of younger and older intrusive rocks seems to be in degree of alteration rather than in kind of alteration.

GEOCHEMICAL INVESTIGATIONS OF THE YOUNGER INTRUSIVE ROCKS

Twenty-one samples of younger porphyry were submitted for semiquantitative spectrographic and chemical analyses. The analytical results suggest scattered weak anomalies in $\mathrm{Ag}, \mathrm{Mo}, \mathrm{Pb}$, and $\mathrm{Zn}$. Bismuth was detected in one sample and tin in another. The outer margin of the younger body (samples CB-11, $-134,-184,-185 \mathrm{a}$, 
pl. 1) appears to have a somewhat higher metal content than the central part of the body.

Comparison of the geochemical results for inclusions of older porphyry with the results for the younger porphyry host indicates significantly disparate metal content. An older porphyry inclusion anomalous in $\mathrm{Ag}, \mathrm{As}, \mathrm{Cu}, \mathrm{Mo}, \mathrm{Pb}, \mathrm{Sb}$, and $\mathrm{Sn}$ (sample $\mathrm{CB}-125$ ) is surrounded by younger porphyry anomalous only in $\mathrm{Ag}$ (sample $\mathrm{CB}-184$ ). The geochemical data indicate that the inclusion contains $500 \mathrm{ppm}$ Mo and $300 \mathrm{ppm} \mathrm{Pb}$ compared with $<5 \mathrm{ppm}$ Mo and $50 \mathrm{ppm}$ $\mathrm{Pb}$ in the younger porphyry host. Geochemical data indicate that another older porphyry inclusion (sample CB-185b) contains $200 \mathrm{ppm}$ Mo compared with $7 \mathrm{ppm}$ Mo in its host rock (sample CB-185a). The geochemical data suggest that the younger body should not be considered truly barren, although metal anomalies are decidedly weaker and more irregularly distributed than those in the older intrusive body. How much of the anomalous metal content of younger rocks was caused by assimilation of metallized older rocks during intrusion of the younger body is impossible to determine.

\section{VEIN DEPOSITS}

The Precambrian granitic rocks surrounding the Chicago Basin stock are cut by numerous quartz-pyrite fissure veins containing local ore shoots of base and precious metals. Most of the veins are localized along a north-northwest-trending belt about 2 miles wide and 4 miles long. The metallized veins mostly fill regional fractures but they also fill fractures discordant with regional trends. Results of geochemical studies suggest that many vein-associated metallic elements are zonally distributed; and the zonal distribution patterns indicate a focus of vein metallization in Vallecito Basin.

\section{DISTRIBUTION OF VEINS}

A south-southeast-trending belt of metallized veins extends from north of the stock through Chicago and Vallecito Basins and across East Silver Mesa and Crystal Valley to Logtown (pl. 1). The belt can be conveniently separated into three areas: Chicago Basin, Vallecito Basin, and southern area. The areas are separated by geological or geochemical contrasts, but together they likely resulted from one mineralizing episode. Metallized veins or shear zones also cut Precambrian rocks west of Chicago Basin near the confluence of New York Gulch with Needle Creek (pl. 1). This western area was not examined in the same detail as the others and its relation to the rest of the district is unclear.

MINERALOGY AND PARAGENESIS

Vein constituents were studied mostly by examining and sampling dump rock from numerous adits, shafts, and prospect pits. Direct ex- 
amination of the veins was limited because the walls and backs of accessible underground workings were obscured by hardened mine dust and oxidation products.

Three stages of vein mineralization were recognized during field studies: an early quartz-pyrite stage, a more localized base-metal stage, and a late comb quartz stage. The bulk of most veins consists of early quartz and pyrite. During the base-metal stage one or more of the minerals sphalerite, galena, chalcopyrite, tetrahedrite, pyrite, quartz, rhodochrosite, calcite, fluorite, and barite were introduced along refractured parts of the early quartz-pyrite veins. Silver and gold probably are contained within the primary sulfide minerals. The veins were subsequently reopened locally and comb quartz was introduced. Minerals of all three stages are present together only locally.

Quartz and pyrite of the early stage generally form fine-grained massive gray to milky-white aggregates. Analyses of some barren-appearing quartz-pyrite samples show small amounts of base or precious metals. However, it is difficult to determine whether these samples have been weakly metallized during the main stage of base-metal activity.

Base metals were introduced largely during a complex stage of fracturing of early quartz-pyrite veins. Quartz was introduced at least two or three times following local refracturing during the base-metal stage. Some second-stage quartz is coarsely crystalline and is not readily distinguishable from later comb quartz. The pyrite introduced with base metals is generally more coarsely crystalline than the early, fine-grained pyrite, and commonly forms aggregates of pyritohedrons. Highly pyritic parts of the veins commonly contain abundant chalcopyrite. Sphalerite and galena are the most abundant ore minerals in nearly all veins sampled. Tetrahedrite is generally subordinate to other sulfides. In a few samples small amounts of bornite, enargite, covellite, colusite(?), stephanite or polybasite, and crystalline hematite were identified microscopically.

Fluorite and rhodochrosite commonly were deposited during the second stage of mineralization in Chicago Basin and Vallecito Basin; these minerals were not found in the southern or western parts of the district. Calcite and barite occur in the same general area as fluorite and rhodochrosite but are not as abundant nor as widely distributed. Arsenopyrite was identified in samples from outlying veins in the district; the paragenetic position of arsenopyrite is unknown because these samples contain no base-metal ore minerals.

Among the base-metal minerals, sphalerite was introduced early and copper minerals were introduced late. Although galena was deposited earlier than the copper minerals in a few places, it was generally contemporaneous with chalcopyrite and tetrahedrite. In 
many samples sphalerite deposition was followed by fracturing and introduction of quartz before galena and copper minerals were deposited. Carbonate gangue minerals were apparently introduced with galena and copper minerals and generally were followed by quartz and fluorite. The late quartz and fluorite may be a final pulse of the base-metal stage or they may belong to the late comb quartz stage. In some samples both sphalerite and galena were deposited before intrastage fracturing. Fracturing was then followed by introduction of quartz and copper minerals. Paragenetic relations among the late sulfides are unclear. Mutual boundaries and so-called replacement textures are common but crosscutting relations are generally lacking. In some $\mathrm{Pb}-\mathrm{Zn}$ ores galena has extensively replaced sphalerite; in some highly pyritic ores chalcopyrite has extensively replaced pyrite. Pyrite commonly contains microscopic rounded blebs of galena, chalcopyrite, tetrahedrite, bornite, and perhaps other minerals. Some of the blebs are composed of several minerals, each with mutual boundary contacts.

Colorless to milky-white comb quartz fills vugs and fractures formed late in the sequence of mineralizing activity. In some veins it is evident megascopically that the base-metal ores have been broken and healed with comb quartz. In others only vugs and small fractures have been filled with comb quartz. It is not clear whether late comb quartz should be considered a separate stage in the mineralizing process or a final pulse of the base-metal stage. Where ore minerals have clearly been broken and subsequently healed with comb quartz, recognition of a separate stage is warranted. However, this relation was not observed in all veins and some comb quartz was clearly introduced along with the base metals. As seen microscopically, some comb quartz consists of phantom quartz crystals with two to five growth bands. Crystals with five growth bands appear to show consistent growth characteristics that can be correlated with most other crystals. Comb quartz with cyclic growth character is paragenetically late in the mineralizing process, whether late in the base-metal stage or as a separate late comb quartz stage.

A shallow oxidized zone a few inches to a few feet deep overlies primary sulfides in most of the veins in Chicago Basin and Vallecito Basin. Over high ridges and adjacent slopes oxidation of sulfides has penetrated to depths of at least 100 feet from the surface. Oxidation has resulted in sparse secondary minerals other than iron and manganese oxides. Supergene azurite, covellite and malachite after chalcopyrite, hydrozincite after sphalerite, and surficial coatings of anglesite on galena were formed locally. 


\section{STRUCTURAL CONTROL}

Most of the quartz-pyrite veins exposed in the Needle Mountains district are controlled by generally north trending or east trending regional fractures. These veins are mostly narrow and discontinuous but locally they are highly metallized. Displacements along these structures appear to be minor but are difficult to judge because of the homogeneous character of country rock. In Vallecito Basin more regional fractures are vein filled than elsewhere, suggesting that tensional fracture spreading was concentrated there.

Radial fractures extending outward from the Chicago Basin stock have localized at least one major metallized vein and one significant altered zone. The vein, named the Aztec, is one of the widest and most continuous metallized veins in the district; it extends at least 6,000 feet S. $10^{\circ} \mathrm{E}$. from just south of the stock, over Aztec Mountain, and into the headwaters of Missouri Gulch (pl. 1). An altered silicic porphyry dike coincides with the northern part of the vein. The vein dips steeply east and the trend of the vein parallels the regional fracture trend. The size and continuity of the vein indicate that radial spreading probably was involved in its formation. A major altered zone extends for about a mile from Columbine Pass S. $55^{\circ} \mathrm{E}$. into Vallecito Basin. An altered flow-structured silicic dike follows the zone in Vallecito Basin (pl. 1); rocks adjacent to the dike consist of an inner envelope of intensely silicified granite about 20 feet wide and an outer envelope of bleached altered granite about 40 to 50 feet wide. The altered zone is considered especially significant because it extends radially out from the Chicago Basin stock and is spatially related to the metallized fissure veins in Vallecito Basin. Sparse evidence of metallization and analogy with the Aztec vein suggest that the structure may be more extensively metallized at depth.

Two major subparallel east-trending fractures with divergent distal branches were traced along the northernmost part of the mesas south of Chicago Basin (pl. 1). To the east, one of the branches trends $\mathrm{N}$. $70^{\circ} \mathrm{E}$., and is exposed for more than 3,000 feet from just south of Bullion Mountain into southern Vallecito Basin. The other branch trends $\mathrm{N} .70^{\circ}-75^{\circ} \mathrm{W}$., and is exposed for more than 5,000 feet from south of Bullion Mountain over Trimble Pass and through Lake Lillie to the divide southeast of Florida Mountain. Both structures dip nearly vertically and have localized surficially barren quartz veins as much as 20-30 feet wide. The potential of these veins for metallization at depth has not been explored.

Another major east-trending fracture zone was traced along the north side of Needle Creek from the lower part of New York Gulch to the Chicago Basin stock (pl. 1). The structure is conspicuous on aerial 
photographs but is barely visible on the ground. Where examined in the field the fracture zone was not filled with vein material, and its mineral potential is therefore unknown.

An overview of the structural pattern suggests that a north-northwest-trending belt of discontinuous vein-filled regional fractures is crossed by an east-trending zone of relatively continuous fractures or faults. The belt of vein-filled fractures appears to be a zone of greater relative spreading of old fissures with a focus in Vallecito Basin. The east-trending zone includes the fractures cutting across the northern parts of the mesas, a paralleling fracture just north of Needle Creek, and several east-trending fractures located between upper Johnson Creek and Grizzly Gulch (pl. 1). The Chicago Basin stock and a concentration of metallized veins are localized within the area of intersecting structural zones.

\section{GEOCHEMICAL INVESTIGATIONS}

About 200 samples from veins, associated wallrock, and altered fracture zones were analyzed by semiquantitative spectrographic and chemical methods. The results are summarized but the geochemical data are not tabulated here because distributions of specific metals may be more apparent than real. In addition to abundant $\mathrm{Cu}, \mathrm{Pb}$, and $\mathrm{Zn}$, anomalous amounts of $\mathrm{Ag}, \mathrm{As}, \mathrm{Au}, \mathrm{Ba}, \mathrm{Bi}, \mathrm{Cd}, \mathrm{Mn}, \mathrm{Mo}, \mathrm{Sb}, \mathrm{Sn}$, and $\mathrm{W}$ were detected in many samples. The same metals that were detected in anomalous amounts in samples taken from the Chicago Basin stock were also detected in anomalous amounts in samples taken from veins. However, no simple zonation around the stock satisfactorily accounts for the geochemical relationships. The interrelations between geochemical anomalies, rock alteration, and geology of the mineralized area are shown in figure 7.

In veins in Chicago Basin, Vallecito Basin, and the southern part of the district, geochemical anomalies appear to be characterized by different suites of metals - in Chicago Basin by $\mathrm{Ag}, \mathrm{As}, \mathrm{Cu}, \mathrm{Mo}, \mathrm{Pb}$, $\mathrm{Sb}, \mathrm{Sn}$, and $\mathrm{Zn}$; in Vallecito Basin by the same suite but more strongly and with additional $\mathrm{Bi}$ and perhaps $\mathrm{Au}$; and in the southern part of the district by $\mathrm{Ag}, \mathrm{As}, \mathrm{Au}, \mathrm{Mo}, \mathrm{Pb}$, and $\mathrm{Zn}$. Insufficient samples were available to establish the significance and extent of anomalous metals detected in the western part of the district, but an As-Au association is suggested.

FIGURE 7.-Sketch map of the mineralized area showing interrelations between geochemical anomalies, rock alteration, and geology. Dotted lines are drainage divides. Heavy solid lines indicate veins and fractures. Crosshatch pattern indicates the stock. Diagonal pattern indicates areas of general rock alteration. Areas outlined by long-dashed lines contain rocks anomalous in Mo. Areas with stipple pattern contain veins decidedly anomalous in $\mathrm{Bi}$ and $\mathrm{Sn}$. Areas outlined by short-dashed lines contain veins highly anomalous in $\mathrm{Ag}, \mathrm{As}, \mathrm{Cu}$, and $\mathrm{Sb}$. 


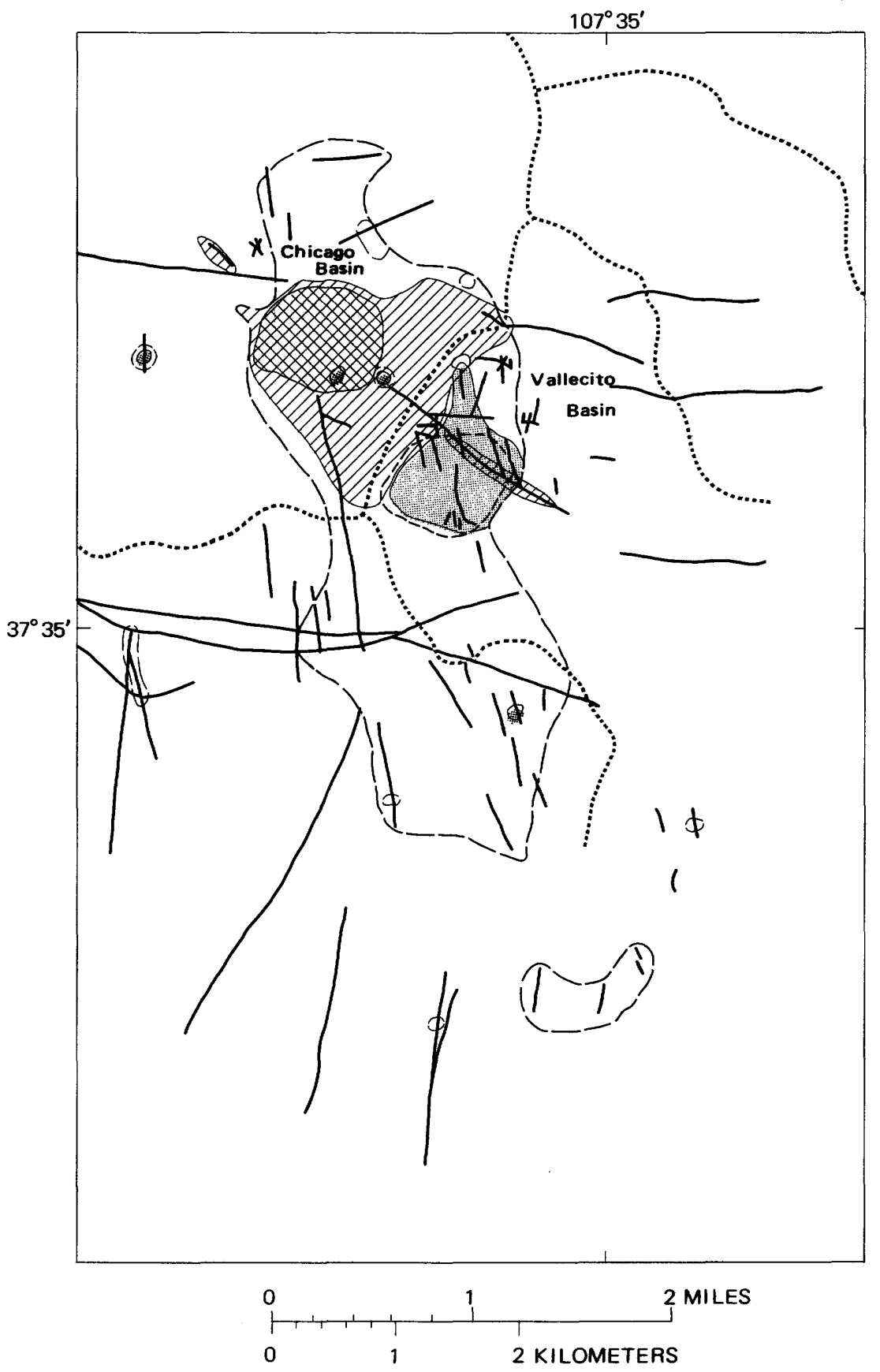


The distributions of $\mathrm{Cu}, \mathrm{Bi}$, and $\mathrm{Ag}$ and of $\mathrm{Zn}: \mathrm{Pb}$ ratios over the district suggest zonal patterns. Geochemical data show zinc generally in excess of lead in Chicago and Vallecito Basins but show the reverse relation in the southern area. Lead appears to increase relative to zinc away from the Chicago Basin stock. Copper and bismuth are apparently concentrated in Vallecito Basin relative to other areas. Anomalously high bismuth is virtually restricted to Vallecito Basin. Silver is widely distributed in anomalous amounts, but in Vallecito Basin and in the central part of the southern area, it is highly anomalous.

Zinc and lead contents range from trace amounts to as much as $\mathbf{2 5}$ percent, reflecting relative amounts of sphalerite and galena. Hence, $\mathrm{Zn}: \mathrm{Pb}$ ratios are considered more useful geochemically. Lead generally increases relative to zinc away from the Chicago Basin stock, the apparent center of zinc-lead zonation. This geochemical relation is consistent with the general distribution of sphalerite and galena determined from field observations. Cadmium was detected in all sphalerite-rich samples and high $\mathrm{Cd}$ values simply reflect high $\mathrm{Zn}$ values. The average $\mathrm{Cd}: \mathrm{Zn}$ value determined from geochemical data is about 1:140.

Copper is distributed in highly anomalous amounts throughout the district but apparently in strongest concentrations in Vallecito Basin. Copper analyses represent a combined contribution from the minerals chalcopyrite and tetrahedrite. The zonal patterns for copper and for zinc-lead appear to be somewhat discordant.

Silver is widely distributed and is concentrated in two areas Vallecito Basin and the central part of the southern area. Silver was determined from trace amounts to a few tenths of a percent but mostly in the 50-200 ppm range. In unoxidized samples silver may be associated with the mineral tetrahedrite or galena inasmuch as silver minerals were generally not detected microscopically. However, the mineral host for anomalous silver has not been established. A few tiny grains of stephanite or polybasite were identified microscopically in sample CB-182 (pl. 1). Native silver and argentite may occur locally in oxidized ores but these minerals were not found in any of the samples examined here.

Gold appears to be much less abundant than silver but is widely distributed in low-level amounts. Locally rich pockets of gold were reported from oxidized ores during the early days of mining (Cross and others, 1905, p. 13). Samples of oxidized ore generally contain more gold than unoxidized samples. Only four samples contained more than $5 \mathrm{ppm}$ gold. One of the high-gold samples is from the western area (sample CB-145c, pl. 1), and two are from the southern area (samples CB-196, -258 , pl. 1). There is the suggestion of a gold halo fringing the district. 
Antimony is most abundant in northern Vallecito Basin, and the zonal pattern of anomalous amounts of antimony is very similar to that of anomalous amounts of copper. Both antimony and copper occur in the mineral tetrahedrite, and the copper-antimony zonal pattern probably reflects in part the distribution of tetrahedrite.

Arsenic is apparently almost as widely distributed as antimony. The higher threshold of arsenic detection by spectrographic methods (200 ppm versus $100 \mathrm{ppm}$ for $\mathrm{Sb}$ ) may obscure an equally wide distribution. Arsenic appears to be somewhat concentrated in northern Vallecito Basin and along the fringes of the district. Arsenic is combined in the mineral arsenopyrite and it may substitute for antimony in tetrahedrite. The arsenic anomaly in Vallecito Basin appears to be associated with tetrahedrite, but the anomaly fringing the district is more closely associated with arsenopyrite. Arsenopyrite was identified in samples taken from the western area (sample CB-145c, pl. 1) and the southern area (sample CB-261, pl. 1). Hence, the arsenic center in Vallecito Basin and the arsenic halo fringing the district appear to be caused by different types of mineralization.

Bismuth apparently has the most restricted distribution of all of the metals. A strong, well-defined bismuth anomaly is located in Vallecito Basin. Nearly all samples anomalously high in $\mathrm{Bi}$ are anomalously high in $\mathrm{Cu}$, but the reverse relation does not hold. No bismuth minerals were identified with certainty in any samples. The presence of anomalous amounts of bismuth is commonly associated with a near. by igneous source.

Tin follows a pattern similar to but less restricted than bismuth, but the tin anomaly in Vallecito Basin is apparently weaker than the corresponding bismuth anomaly. All samples containing tin in highly anomalous amounts contain bismuth, but the reverse relation does not hold. Within Vallecito Basin the distribution of tin is very similar to the distribution of antimony, and all samples containing tin in highly anomalous amounts also contain copper in highly anomalous amounts. Sample CB-124 (pl. 1), which contains a highly anomalous amount of tin, contains a mineral tentatively identified as colusite in intimate association with major tetrahedrite and minor enargite. Sample CB-225 (pl. 1), which also contains a highly anomalous amount of tin, contains no tin minerals detectable by X-ray diffraction methods. The mineral host for tin is uncertain in most samples. Tin may indicate closer proximity to an igneous source than bismuth.

Tungstin was detected, and is therefore anomalous, in 11 samples. The relatively high threshold of tungsten detection by spectrographic methods, $50 \mathrm{ppm}$, obscures any weaker anomalies that may be present. Too few samples contained tungsten to suggest zonal patterns.

Molybdenum was consistently present in anomalous amounts in samples taken from the entire metallized belt, and no apparent zona- 
tion in the distribution of vein-associated Mo was detected. Molybdenite flakes or rosette aggregates were identified in samples CB-120, -164, -167, and -260 (pl. 1). A spectrographic analysis of a molybdenite concentrate (taken from sample CB-167) indicated that $\mathrm{Ag}, \mathrm{Ba}, \mathrm{Bi}, \mathrm{Cu}, \mathrm{Ge}, \mathrm{Pb}, \mathrm{Sn}$, and $\mathrm{W}$ are present in significant amounts. The concentrate is apparently highly anomalous in $\mathrm{Pb}(2,000 \mathrm{ppm})$ and $W(300 \mathrm{ppm})$. The rhenium content of the concentrate (estimated 70-80 percent molybdenite) was determined to be $31 \mathrm{ppm}$, which is not considered high for molybdenites (R. U. King, U.S. Geol. Survey, oral commun., 1970). Molybdenum is apparently concentrated more in the immediate wallrock of veins than within veins. This relation is clearly seen at sample site CB-167 (pl. 1), where altered granitic wallrock from a quartz vein contains rosette aggregates of molybdenite. Molybdenite was seen in very few samples of vein material, and it was not seen microscopically in any vein samples rich in base-metal sulfides. Molybdenum is probably one of the earliest metals introduced along vein channels. However, not all molybdenum in the district may belong to the same genetic episode of metallization. At sample site CB-260 (pl.1) molybdenite-bearing pegmatitic Eolus Granite was found in dump rock from a small prospect. Therefore, an older episode of molybdenite mineralization may also have occurred in the district.

\section{GEOLOGIC IMPLICATIONS}

In the Needle Mountain district, a composite stock in Chicago Basin is surrounded by numerous outlying metallized veins. One porphyry body in the Chicago Basin stock is zonally altered and locally mineralized with molybdenite, and shows many aspects of a "porphyry-type" disseminated molybdenum deposit. Anomalous amounts of several metals detected geochemically coincide with areas of most intense sericitic alteration and molybdenite mineralization in the stock. Elsewhere, quartz-pyrite veins locally rich in base metals fill fractures throughout the district. Metal anomalies detected geochemically in veins are strongest in Chicago and Vallecito Basins where structural zones intersect. In Vallecito Basin more fractures are vein filled than elsewhere, and metal anomalies are concentrated there. Some metal distributions suggest another focus of metallization in the southern part of the district, but the geochemical and structural foci are not as well defined as in Vallecito Basin.

The Chicago Basin stock consists of a highly altered granite porphyry body intruded by a less altered rhyolite porphyry body. The older body has a coarser grained core and finer grained chilled margin. Nearly all rocks in the older body are altered to quartz-sericite-pyrite or quartz-sericite-kaolinite-pyrite assemblages; sericitic alteration of the rocks is most intense on the west side of the older body where quartz veinlets, local concentrations of disseminated molybdenite, and 
the strongest geochemical anomalies virtually coincide. Rocks are less altered and metal anomalies are weaker on the east side of the older body; but locally, highly broken rocks, possibly parts of breccia pipes contain an advanced argillic alteration-mineral assemblage. The southeast margin of the adjacent younger body contains molybdenitebearing inclusions of the older porphyry that presumably were derived from depths below presently exposed levels. The economic potential of the Chicago Basin stock seems worthy of further investigation.

The distribution of mineralized fissures and the zonal pattern of anomalous metal concentrations suggest that the mineralized stock and veins may be manifestations of a larger intrusive body at depth. Preliminary aeromagnetic interpretations (Popenoe and Steven, 1969) tend to support this interpretation. Chicago Basin and Vallecito Basin are within an area where strong east-trending fractures intersect strong generally north trending fractures. In addition, the district-wide distribution of fissure veins suggests widespread tensional spreading of fractures. More fissure veins are localized in Vallecito Basin than in other areas, suggesting locally concentrated spreading, and most vein-associated metal anomalies are also centered in Vallecito Basin rather than being zoned around the Chicago Basin stock. Although many vein-associated metals are anomalously high in Chicago Basin, only $\mathrm{Zn}$ and $\mathrm{Pb}$ appear to be zonally arranged around the stock. Vein-associated fluorite and the strongest vein associated $\mathrm{Ag}, \mathrm{Bi}, \mathrm{Cu}, \mathrm{Sb}$, and $\mathrm{Sn}$ anomalies, which are believed to indicate proximity to an igneous source, are much more common in the highly fractured area in Vallecito Basin. In contrast, samples taken from veins near the center of the southern part of the district contain highly anomalous amounts of $\mathrm{Ag}$, sparse $\mathrm{Bi}$, and almost no detectable $\mathrm{Sn}$. These features suggest that a local pluton, perhaps a cupola on a larger underlying body and similar to the Chicago Basin stock, may underlie the metallized veins in Vallecito Basin.

\section{REFERENCES CITED}

Barker, Fred, 1969, Precambrian geology of the Needle Mountains, southwestern Colorado: U.S. Geol. Survey Prof. Paper 644-A, 35 p.

Creasey, S. C., 1959, Some phase relations in the hydrothermally altered rocks of porphyry copper deposits: Econ. Geology, v. 54, no. 3, p. 351-373.

Cross, Whitman, Howe, Ernest, Irving, J. D., and Emmons, W. H., 1905, Description of [the] Needle Mountains quadrangle [Colorado]: U.S. Geol. Survey Geol. Atlas, Folio 131.

Daly, R. A., Larsen, E. S., Jr., and LaForge, Laurence, 1942, Composition of igneous rocks, stony meteorites, and iron meteorites, in Handbook of physical constants: Geol. Soc. America Spec. Paper 36, sec. 1, p. 1-5.

Deer, W. A., Howie, R. A., and Zussman, J., 1962, Rock-forming minerals_-Volume 3, Sheet silicates: New York, John Wiley and Sons, Inc., 270 p.

Hemley, J. J., and Jones, W. R., 1964, Chemical aspects of hydrothermal alteration with emphasis on hydrogen metasomatism: Econ. Geology, v. 59, no. 4, p. 538-569. 


\section{0}

Henderson, C. W., 1926, Mining in Colorado-a history of discovery, development, and production: U.S. Geol. Survey Prof. Paper 138, 263 p.

Larsen, E. S., Jr., and Cross, Whitman, 1956, Geology and petrology of the San Juan region, southwestern Colorado: U.S. Geol. Survey Prof. Paper 258, 303 p.

Popenoe, Peter, and Steven, T. A., 1969, Interpretation of the aeromagnetic pattern of the San Juan primitive area, Colorado: U.S. Geol. Survey Open-File Rept., 7 p.

Steven, T. A., Schmitt, L. J., Jr., Sheridan, M. J., and Williams, F. E., 1969, Mineral resources of the San Juan primitive area, Colorado: U.S. Geol. Survey Bull. $1261-\mathrm{F}, 187 \mathrm{p}$.

Vanderwilt, J. W, Burbank, W. S., and Traver, W. M., Jr., 1947, Mineral resources of Colorado: Colorado Mineral Resources Board, 547 p.

Worcester, P. G., 1919, Molybdenum deposits of Colorado: Colorado Geol. Survey Bull. $14,131 \mathrm{p}$.

Yoder, H. S., Jr., and Eugster, H. P., 1955, Synthetic and natural muscovites: Geochim. et Cosmochim. Acta, v. 8, no. 5, 6, p. 225-280. 
